\title{
Two homeo domain proteins bind with similar specificity to a wide range of DNA sites in Drosophila embryos
}

\author{
Johannes Walter, Chad A. Dever, and Mark D. Biggin \\ Department of Molecular Biophysics and Biochemistry, Yale University, New Haven, Connecticut 06520 USA
}

\begin{abstract}
We have used in vivo UV cross-linking to directly measure DNA binding by the homeo domain proteins even-skipped (eve) and fushi tarazu (ftz) in Drosophila embryos. Strikingly, these two proteins bind at uniformly high levels throughout the length of their genetically identified target genes and at lower, but significant, levels to genes that they are not expected to regulate. The data also suggest that these two proteins have very similar DNA-binding specificities in vivo. In contrast, a non-homeo domain transcription factor, zeste, is only detected on short DNA elements within a target promoter and not on other genes. These results are consistent with the in vitro properties of these various proteins, their respective concentrations in the nucleus, and with earlier predictions of how transcription factors bind DNA in vivo. We propose that these data favor the model that $e v e, f t z$, and closely related homeo domain proteins act by directly regulating mostly the same target genes.
\end{abstract}

[Key Words: even-skipped; fushi tarazu; zeste; in vivo cross-linking; homeo domain proteins]

Received April 14, 1994; revised version accepted June 8, 1994.

In Drosophila, the segmentation and homeotic genes play a key role in establishing the body plan of the embryo (Garcia-Bellido 1975; Lewis 1978; Nüsslein-Volhard and Wieschaus 1980; Akam 1987). The segmentation genes are transcribed first, and one of their functions is to initiate the patterns of homeotic gene expression. Both the segmentation and homeotic genes appear to direct morphogenesis by regulating the expression of a great many other genes, some of which have been identified /Garcia-Bellido 1975; Cohen 1990; Immerglück et al. 1990; Gould and White 1992; Vachon et al. 1992; O'Hara et al. 1993; Capovilla et al. 1994).

The homeotic genes and several of the segmentation genes encode proteins that contain a highly conserved DNA-binding domain termed the homeo domain (McGinnis et al. 1984; Scott and Weiner 1984; Desplan et al. 1985). The segmentation proteins even-skipped (eve), engrailed, and fushi tarazu (ftz) and all the homeotic proteins have a glutamine at position 50 of the homeo domain (Q50 homeo domain proteins), and these proteins bind with similar affinities to the same wide range of specific DNA-binding sites (Desplan et al. 1988; Hoey and Levine 1988; Laughon et al. 1988; Biggin and Tjian 1989a; Hanes and Brent 1989; Treisman et al. 1989; Appel and Sakonju 1993). Homeo domain proteins have also been shown to regulate transcription in tissue culture cells and in in vitro transcription reactions, supporting the model that they act as transcription factors to control development (for review, see Biggin and Tjian 1989b; Hayashi and Scott 1990).
To understand the mechanisms by which Q50 homeo domain proteins control development, it is essential to determine which DNA elements they bind in embryos. Identifying these natural target sequences has been extremely difficult for the following reasons (for discussion, see Biggin and Tjian 1989b; Hayashi and Scott 1990). First, the regulatory hierarchy involving homeo domain proteins is highly complex and possibly quite redundant. Therefore, the power of genetic analysis in predicting which interactions may be direct is severely reduced. Second, because different Q50 homeo domain proteins bind the same sequences in vitro and are sometimes coexpressed in the same cells, they may compete for DNA-binding sites in vivo, and it is difficult to predict the outcome of such competition. Third, it is possible that in the complex environment of the embryo, the DNA-binding specificities of homeo domain proteins are markedly different from those observed in vitro.

The above complexities have made it impossible to distinguish among a range of models for the action of Q50 homeo domain proteins in development (e.g., see Winslow et al. 1989; Hayashi and Scott 1990; Dessain et al. 1992; Ekker et al. 1992; Lawrence 1992). At one extreme, it has been suggested that these proteins may all recognize the same DNA sequences in vivo, just as they do in vitro, and regulate the same targets. At the other extreme, different Q50 homeo domain proteins may bind highly distinct DNA elements in vivo and frequently regulate different target genes. This latter type of model has been proposed to account for observations such as 
the following: Loss-of-function mutations in different homeo domain proteins do not always affect expression of the same downstream genes (e.g., Carroll and Scott 1986; Harding et al. 1986; Frasch et al. 1988); also, transgenic experiments reveal that when two Q50 homeo domain genes affect expression of the same downstream gene, their respective effects are often mediated through different regulatory elements (e.g., see Müller and Bienz 1992; Vachon et al. 1992; O'Hara et al. 1993). In this paper we have sought to determine whether DNA binding by Q50 homeo domain proteins conforms to either of the above models or to some intermediate model. To this end, we used in vivo cross-linking to directly measure and compare DNA binding by the two Q50 homeo domain proteins eve and $f t z$ on numerous genes in living embryos.

\section{Results}

To identify bona fide DNA targets of homeo domain proteins, we chose an existing in vivo UV cross-linking assay (Gilmour and Lis 1986; Rougvie 1989) that can distinguish DNA binding by members of a family of proteins that recognize the same sites. In this technique, UV light is used to induce covalent bonds between protein and DNA in vivo; protein-DNA complexes are then isolated by immunoprecipitation and characterized by Southern blotting (Fig. 1). A major strength of this approach is that UV light induces covalent bonds only between protein and nucleic acid residues that are in intimate contact with one another (Hockensmith et al. 1991 and references therein; Blatter et al. 1992). Also, crosslinking is directly proportional to the occupancy of a

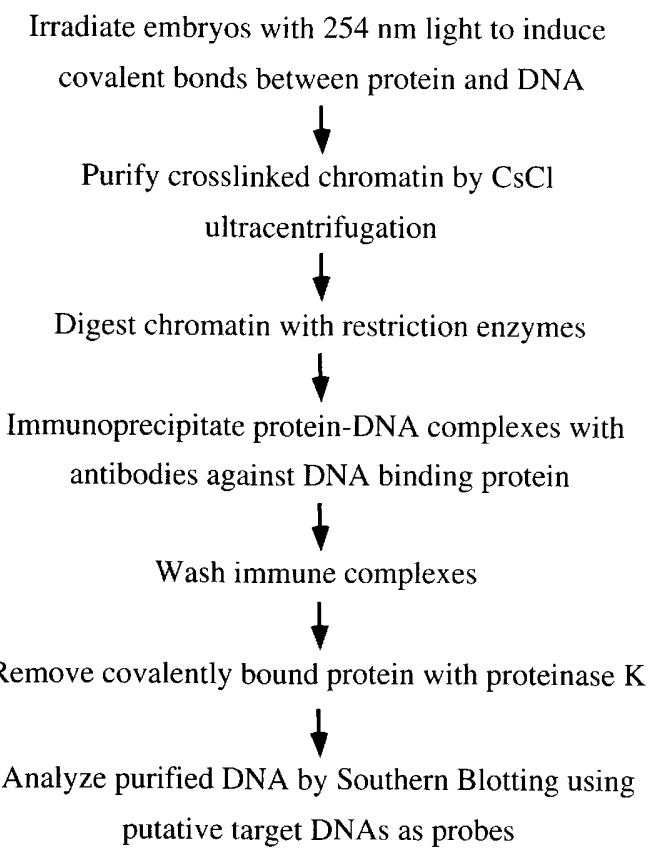

Figure 1. The in vivo UV cross-linking method of Gilmour and Lis $(1985,1986)$. protein on its binding site (Hockensmith et al. 1991; Williams and Konigsberg 1991). As a result, it has been possible to use in vivo UV cross-linking to locate binding sites of several proteins in vivo /Gilmour and Lis 1986; Gilmour et al. 1986; Rougvie 1989; Champlin et al. 1991). For example, a paused RNA polymerase II molecule has been mapped to high resolution with UV crosslinking in tissue culture cells (Gilmour and Lis 1986), and the accuracy of this mapping was independently confirmed using in vivo footprinting (Giardina et al. 1992) and mapping of partially transcribed RNAs (Rougvie and Lis 1988).

This method has not been employed previously to study sequence-specific transcription factors, and our preliminary attempts to do so were unsuccessful because these factors cross-link to DNA much less efficiently than RNA polymerase II (J. Walter and M.D. Biggin, unpubl.). We therefore improved the sensitivity of the method by 100 -fold so that DNA binding of sequencespecific transcription factors could be detected (see Materials and methods).

\section{zeste binds directly to the endogenous Ubx gene} in embryos

To verify that this modified UV cross-linking method also detects only specific protein-DNA interactions, we first used it to study DNA binding by the non-homeo domain transcription factor zeste. Unlike homeo domain proteins, zeste is not a member of a gene family, and its DNA binding is very specific in vitro (Benson and Pirrotta 1987, 1988; Biggin et al. 1988; Laney and Biggin 1992). These properties have made it possible to identify a cluster of five high affinity zeste protein-binding sites in the Ultrabithorax $(U b x)$ proximal promoter that are very probably bound by zeste protein in the embryo (Biggin et al. 1988; Laney and Biggin 1992). The modified cross-linking method was tested by determining whether zeste protein could be specifically cross-linked to this cluster of sites.

Embryos in which the $U b x$ gene is actively transcribed and which express high levels of zeste protein were UV irradiated, and their chromatin was extracted and restriction digested. Figure 2, lane 7, shows that a 3.5-kb $U b x$ proximal promoter fragment is immunoprecipitated from this chromatin by an affinity-purified anti-zeste antibody. Comparison of this signal with a dilution series of the total DNA present in the reaction prior to the addition of antibody (referred to as "total DNA"; Fig. 2, lanes 1-4) shows that the level of recovery is .005\%. In the absence of zeste antibodies, the yield of promoter fragments is at least 50 -fold lower (Fig. 2, lane 8). To demonstrate the specificity of the antibody for the zeste protein, cross-linking was carried out on homozygous $z^{a e(b x)}$ mutant embryos. These embryos carry an inversion that removes the $3^{\prime}$ half of the zeste gene, abolishing the epitopes that the antibody recognizes (Benson and Pirrotta 1987; Pirrotta et al. 1987). As expected, no $U b x$ promoter sequences are precipitated from these embryos in the presence of zeste antibody (Fig. 2, lane 5). As a 


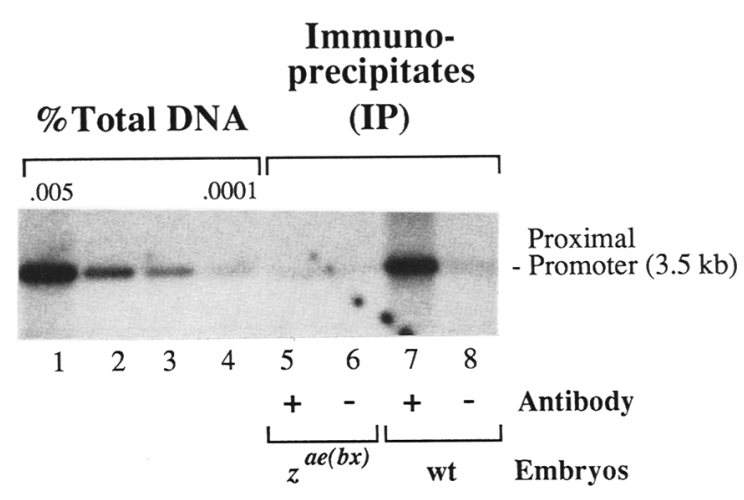

Figure 2. Endogenous zeste protein binds to the $U b x$ promoter in living embryos. Southern blotting shows the results of a UV cross-linking experiment carried out on 8- to 10-hr-old embryos (for details, see Materials and methods). Wild-type (lanes 7,8 ) or homozygous $z^{a e(b x)}$ mutant (lanes $5,6)$ embryos were irradiated with UV light to induce protein-DNA crosslinking, and their chromatin was extracted and purified by $\mathrm{CsCl}$ density ultracentrifugation. Chromatin was digested with EcoRI, and 450- $\mu \mathrm{g}$ aliquots were immunoprecipitated with affinity-purified anti-zeste antibody (lanes 5,7) or mock-precipitated in the absence of antibody (lanes 6,8). Protein-DNA complexes were isolated using fixed Staphylococcus aureus (Staph A) cells and washed extensively. The complexes were then eluted from the Staph A cells and digested with proteinase $\mathrm{K}$, and the purified DNA was separated on a $0.7 \%$ agarose gel. The DNA was analyzed by Southern blotting using a radioactive probe generated by random priming of a 3.5-kb EcoRI $U b x$ promoter fragment (genomic clone 3102; Bender et al. 1983). For quantitation, lanes $1-4$ contain $.005 \%, .001 \%, .0005 \%$, and $.0001 \%$, respectively, of the total DNA present in a single immunoprecipitation reaction prior to the addition of antibody (total DNA). control, it was determined that cross-linking by RNA polymerase II to the actin $5 C$ gene was unaffected in these embryos (data not shown). These results demonstrate that endogenous zeste protein interacts directly with the $U b x$ promoter.

To map zeste cross-linking further within the $3.5-\mathrm{kb}$ Ubx proximal promoter fragment, chromatin from wildtype embryos was digested with both EcoRI and StuI. This separates the promoter into a $1-k b$ fragment surrounding the RNA start site, which includes the cluster of five zeste protein-binding sites, and a $2.5-\mathrm{kb}$ fragment lacking zeste-binding sites /see expanded diagram of the proximal promoter shown in Fig. 3B; see also Benson and Pirrotta 1987). The $1-\mathrm{kb}$ fragment is precipitated just as efficiently as the entire 3.5-kb EcoRI fragment (Fig. 3C, column 2), whereas no recovery of the 2.5 - $\mathrm{kb}$ fragment is observed (Fig. 3C, column 1). Thus, the cross-linking of zeste protein in vivo maps to the region expected based on biochemical and molecular genetic experiments.

Next, we examined the in vivo distribution of zeste protein on a more extensive region of the $U b x$ gene and found an excellent correlation with previous in vitro im-
Figure 3. zeste cross-links to specific regions in $40 \mathrm{~kb}$ of the $U b x$ promoter. $(A)$ Each vertical column shows the result of a UV cross-linking experiment using chromatin from irradiated wild-type 8- to 10-hr old embryos, which was digested with either BamHI (columns 1,2) or EcoRI (columns 3-7). The top lane in each column contains $.005 \%$ of total DNA; the lower two lanes show the results of immunoprecipitations, either in the presence or absence of affinity-purified anti-zeste antibody. Southern blots in columns $1-7$ were probed with the genomic EcoRI or BamHI fragment indicated below each column as a double-headed arrow (genomic fragments $3104,3103,3105,3106,3102,3108$, and 3109, respectively; Bender et al. 1983). (B) Schematic representation of the $U b x$ gene from -30 to $+10 \mathrm{~kb}$ relative to the start site of transcription at +1 . Double-headed arrows represent genomic fragments that were assayed in UV cross-linking experiments, and those that were recovered above background have numbers denoting the efficiency of recovery as a percentage of total DNA. The approximate locations of the PBX and BXD enhancers (Müller and Bienz 1991) are indicated. The 3.5-kb proximal promoter EcoRI fragment is expanded to show the five high affinity zeste protein-binding sites as open ellipses and the two EcoRI-StuI fragments. (B) BamHI; (S) StuI; (R) EcoRI. (C) Mapping of zeste protein within the Ubx proximal promoter. UV cross-linking was carried out as in $A$ except that chromatin was digested with EcoRI and StuI. The blot was probed with a 3.5-kb EcoRI proximal promoter fragment (3102, Bender et al. 1983) that hybridizes to a 2.5 -kb promoter fragment (column 1 ) and a 1 -kb promoter fragment (column 2).

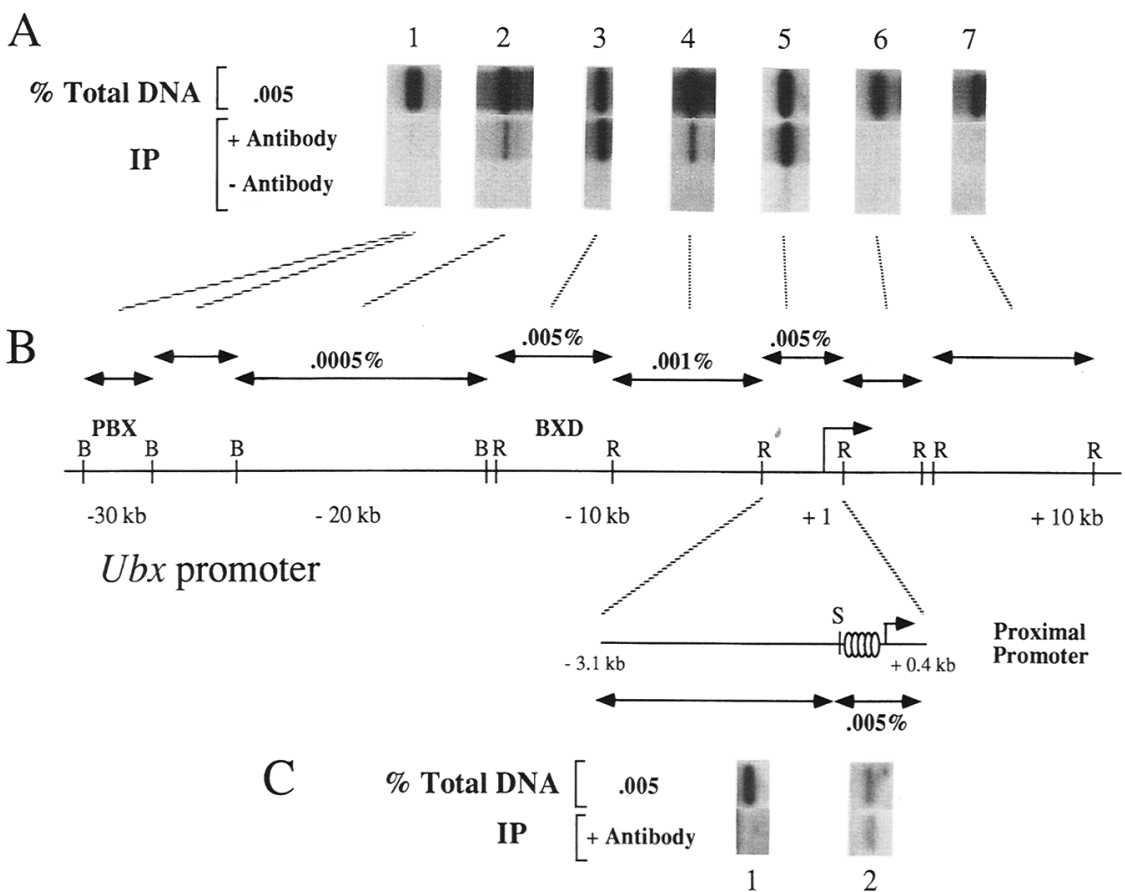


munoprecipitations that mapped zeste protein-binding sites on the same genomic region (Benson and Pirrotta 1988). Four DNA fragments that are bound by zeste protein in vitro were examined, and binding to all these fragments was detected in vivo (Fig. 3A; columns 2-5). Furthermore, three fragments that are not bound by zeste protein in vitro were not recovered above the background of $.00005 \%$ in the UV cross-linking assay (Fig. $3 \mathrm{~A}$, columns $1,6,7)$. The cross-linking per kilobase on each of these latter three fragments is several hundredfold lower than the value on the $1-\mathrm{kb}$ fragment surrounding the $U b x$ transcription start site, suggesting very specific binding by zeste protein in vivo.

Binding of zeste is not detected on the $\mathrm{ftz}$, rosy, actin $5 \mathrm{C}$, or eve genes

To further assess the distribution of zeste protein in vivo, we examined a series of other promoters. The binding of zeste protein to the $\mathrm{ftz}$ promoter was examined because zeste protein does not bind to this promoter in vitro (Benson and Pirrotta 1988). Consistent with this, there was no cross-linking of zeste protein above the background on two $3.5-\mathrm{kb} \mathrm{ftz}$ promoter fragments that span most of the regulatory and transcribed region (Fig. 4A). We also examined binding to sizable portions of the rosy, actin $5 C$, and eve promoters. These promoters have not been assayed for zeste protein-binding sites in vitro, and it is not known whether they are regulated by zeste. None of these promoter fragments were recovered above background levels in UV cross-linking experiments with zeste antibody, suggesting that zeste protein does not bind significantly to these promoters in the embryo (Fig. 4B-D).

In summary, cross-linking by zeste protein maps to characterized zeste protein-binding sites in the $U b x$ gene, and no cross-linking is detected on numerous DNA fragments in $U b x$ and $f t z$ to which no binding by zeste protein is seen in vitro. This agrees with earlier results showing that in vivo cross-linking is limited to the region of contact between protein and DNA (Gilmour and Lis 1986; Rougvie and Lis 1988).

\section{eve binds directly to its own promoter in cellular blastoderm and gastrulating embryos}

Having established the specificity of our more sensitive UV cross-linking assay, experiments were initiated to understand how homeo domain proteins bind to DNA in the embryo. We chose to examine DNA binding by the segmentation proteins $e v e$ and $f t z$, both of which contain Q50 homeo domains. Both of these proteins regulate their own expression, and they also regulate the segmentation gene engrailed and many of the homeotic genes (Akam 1987; Hiromi and Gehring 1987; Frasch et al. 1988). As described in the introductory section, it has been difficult to establish whether these interactions are direct. Also, it is unclear whether related homeo domain proteins like $e v e$ and $f t z$ have similar or different DNAbinding specificities in vivo.
We first examined the binding of eve protein on the eve gene, as it is one of the most studied potential targets of direct eve regulation in vivo (Frasch et al. 1988; Goto et al. 1989; Harding et al. 1989; Jiang et al. 1991). eve is required to maintain high levels of its own expression in narrow stripes of cells during gastrulation, and it is necessary for repression of its own promoter in other cells during the same period. Although promoter elements that mediate this positive and negative autoregulation have been shown to lie within $8 \mathrm{~kb}$ of DNA upstream of the RNA start site, both direct and indirect mechanisms have been invoked to explain this regulation (Jiang et al. 1991; Manoukian and Krause 1992).

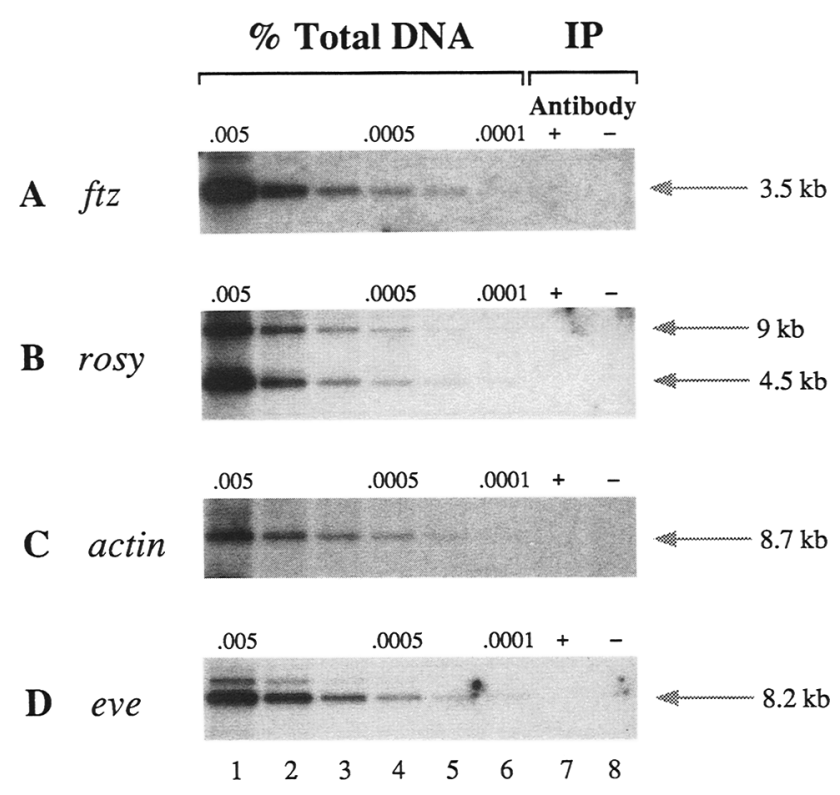

Figure 4. Binding of zeste protein is not detected on the rosy, actin $5 C$, ftz, or eve genes. $(A-D)$ The results of UV cross-linking experiments using EcoRI-digested chromatin from irradiated 8- to 10-hr embryos (as described in Fig. 2). Lanes 1-6 in each blot contain $.005 \%, .002 \%, .001 \%, .0005 \%, .0002 \%$, and $.0001 \%$, respectively, of total DNA; lanes 7 and 8 show the results of immunoprecipitations in the presence (lane 7 ) or absence (lane 8 ) of anti-zeste antibody. The blot in $A$ was probed with a 6.8 -kb KpnI-SalI promoter fragment from the $\mathrm{ftz}$ gene (from plasmid pfK3; provided by Henry Krause, University of Toronto, Canada). It hybridizes to three contiguous EcoRI fragments extending from $-6 \mathrm{~kb}$ to about $+2 \mathrm{~kb}$ relative to the RNA start site (Weiner et al. 1984). Two of these comigrate at a size of $3.5-\mathrm{kb}$ (for a diagram, see Fig. $8 \mathrm{C}$ ). No cross-linking is seen to the third fragment, which is $1.2 \mathrm{~kb}$ in size (data not shown). (B) Probed with a 7.3-kb HindIII fragment from the rosy gene (from plasmid pHZ50PL; Hiromi and Gehring 1987), which hybridizes to two EcoRI fragments ( 9 and $4.5 \mathrm{~kb}$ ) extending from about $-7 \mathrm{~kb}$ to $+6 \mathrm{~kb}$ relative to the RNA start site (Coté et al. 1986). (C) Probed with actin 5C sequences (from plasmid pPac U + NdeI; Biggin and Tjian 1989a) that hybridize to an $8.7-\mathrm{kb}$ EcoRI genomic fragment containing the actin $5 \mathrm{C}$ transcription unit (Fyrberg et al. 1980). (D) Probed with eve promoter sequences from -0.4 to $-6.4 \mathrm{~kb}$ relative to the RNA start site, which hybridize to an $8.2-\mathrm{kb}$ EcoRI eve promoter fragment surrounding the RNA start site (Frasch et al. 1987). 
To determine whether eve protein binds directly to promoter sequences mediating autoregulation, UV crosslinking was carried out on 4- to 5-hr-old embryos (corresponding to the latter half of stage 5 , and stages 6-8 according to Campos-Ortega and Hartenstein 1985). In these embryos, eve expression is at its highest and both positive and negative autoregulation are occurring. Using chromatin from irradiated 4- to 5-hr embryos, an antibody specific for the eve protein precipitates a $7.3-\mathrm{kb}$ $B g l I$ promoter fragment that includes the sequences that mediate positive and negative autoregulation (Fig. 5A, lane 1). The recovery is equivalent to $.005 \%$ of total DNA. In the absence of antibody, or when the embryos are not irradiated, no eve promoter fragment is isolated (Fig. 5A, lanes 2,3). The antibody used in this experiment (amino-terminal eve antibody) was affinity purified from a serum raised against the amino-terminal two-thirds of the eve protein. This serum gives the characteristic seven stripe pattern of eve expression in whole mount embryos with extremely low background (see Materials and methods).

To confirm the specificity of the eve antibody, crosslinking was examined in older embryos in which eve expression is very low. As expected, cross-linking by eve protein was virtually undetectable in two populations of older embryos in which eve expression is either off or limited to a small number of cells (Fig. 5B, lanes 2 and 3, respectively|. As a control, we verified that cross-linking of RNA polymerase II to the actin $5 \mathrm{C}$ gene is virtually the same in old and young embryos (data not shown). To confirm independently that eve protein is bound to its own promoter, we used an affinity-purified polyclonal antibody that recognizes a different portion of the eve protein, the carboxy-terminal region (carboxy-terminal eve antibody; see Materials and methods|. This antibody also precipitated eve promoter DNA in a stage-dependent manner, albeit with about twofold lower yields and a slight background in 8- to 10 -hr embryos (Fig. 5C, cf. lanes 1 and 2 with lanes 3 and 4). Also, serum that has been depleted of $e v e$-specific antibodies by affinity chromatography has no activity in the UV cross-linking assay (Fig. 5C, lane 5).

To provide rigorous proof that this UV cross-linking assay can detect eve-specific cross-linking, the experiment was carried out in Drosophila tissue culture cells. These cells do not normally express eve protein. However, transfection of these cells with an eve expression plasmid leads to repression of a reporter plasmid containing the $U b x$ proximal promoter (Biggin and Tjian 1989a). Under these conditions, the UV cross-linking method detects eve protein binding to the 1.1-kb Ubx proximal promoter fragment present in the reporter plasmid (Fig. $5 \mathrm{D}$, lane 1). If the eve expression plasmid is not cotransfected with the reporter plasmid, background levels of the $U b x$ promoter fragment are isolated (Fig. $5 \mathrm{D}$, lane 2). Because the only parameter altered in this experiment is the level of eve expression, this shows rigorously that the eve antibody detects eve-specific cross-linking.

Taken together, these results argue strongly that eve protein interacts directly with its own promoter and, fur-
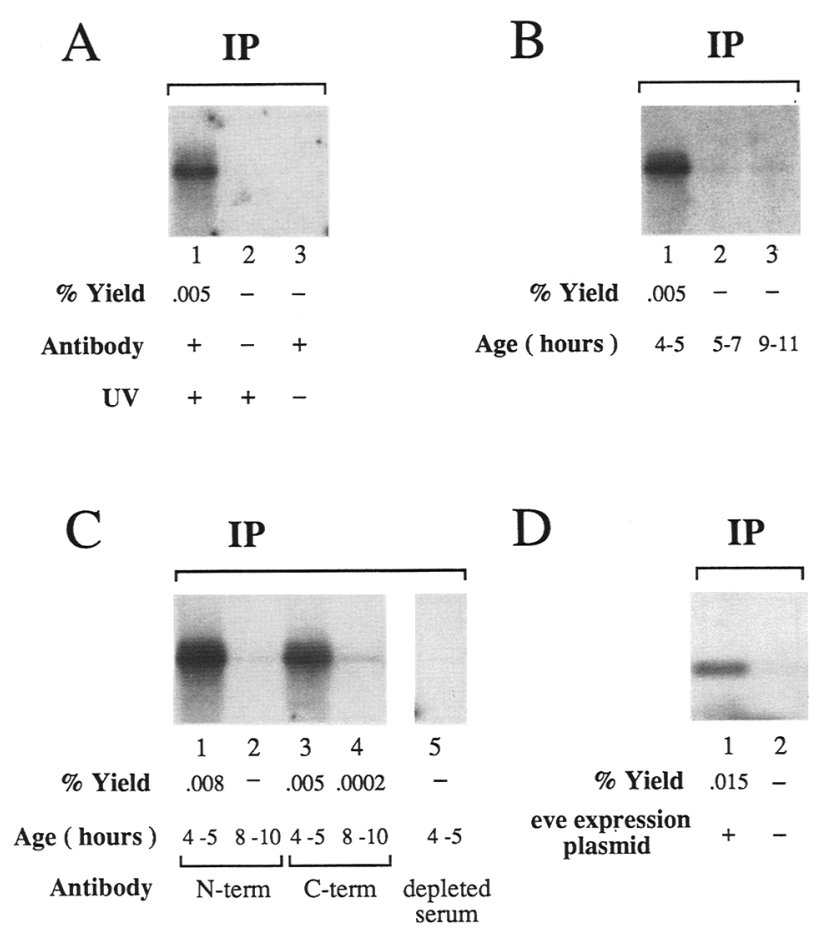

Figure 5. In vivo UV cross-linking of eve protein. In the four UV cross-linking experiments shown in $A-D$, immunoprecipitation yields are indicated based on comparisons with dilution series of total DNA, which are not shown. $(-)$ The signal observed was background. Southern blots in $A, B$, and $C$ were probed with the same probe used in Fig. $4 D$, and the DNA fragment detected is a 7.3-kb eve promoter fragment extending from -0.3 to $-7.6 \mathrm{~kb}$ (see Fig. 6A). (A) Binding of eve protein to the eve promoter. Chromatin was isolated from irradiated 4- to 5-hr old (lanes 1,2) or unirradiated 4- to 5-hr (lane 3) embryos and digested with BglI. Affinity purified amino-terminal eve antibody was present in immunoprecipitations 1 and 3, but not in 2. (B) Binding of eve protein to the eve promoter at different stages in development. Immunoprecipitations as described in $A$ were carried out with irradiated chromatin from 4- to 5-hr (lane 1), 5- to 7-hr (lane 2; contains stages 9 and 10), or 9- to $11-\mathrm{hr}$ (lane 3; contains predominantly stages 11 and 12) embryos. Though we have defined as background the low levels of eve promoter fragments that are immunoprecipitated from older embryos (equivalent to $\sim .0001 \%$ of total DNA), this could represent DNA-binding by the low level of eve protein being expressed in these embryos. $(C)$ eve cross-linking is also detected with a second-affinity purified antibody. Immunoprecipitations were performed with BglI-digested chromatin from irradiated 4to 5 -hr (lanes 1,3,5) or 8- to 10-hr (lanes 2,4) embryos. Reactions contained amino-terminal eve antibody (lanes 1,2), carboxy-terminal eve antibody (lanes 3,4), or serum that had been depleted of eve-specific antibodies by affinity chromatography (lane 5). $(D)$ eve protein cross-linking in tissue culture cells. UV crosslinking was carried out on Schneider cells (see Materials and methods) that were transfected with a CAT reporter plasmid containing $U b x$ proximal promoter sequences from -600 to +360 relative to the RNA start site. Cells used for the reaction in lane 1 were cotransfected with an eve expression plasmid, pPac $\mathrm{U}+N d e \mathrm{I} e v e$; cells used for the reaction in lane 2 were transfected with a control plasmid. The chromatin in both reactions was digested with both EcoRI and BamHI and the blot was probed with the same probe used in Fig. 3A. 
thermore, that any cross-linking above the background of $.0001 \%$ in embryos represents eve molecules bound to DNA. It is not known which eve-expressing cells give rise to the cross-linking signals. However, the relatively undifferentiated state of the tissue and the fact that eve appears to control eve expression very similarly in all seven eve stripes makes it likely that the cross-linking observed is representative of binding in most or all eveexpressing cells.

\section{eve protein binds throughout $10-\mathrm{kb}$ of the eve promoter}

To map more closely the regions to which eve protein binds, $\sim 10 \mathrm{~kb}$ of the eve promoter extending from -7 to $+3 \mathrm{~kb}$ relative to the RNA start site was divided into $\sim 1.5$-kb fragments using different restriction enzymes. Cross-linking of eve protein to each fragment was determined in 4- to 5-hr embryos and, as a negative control, in 8- to $10-\mathrm{hr}$ embryos. In Fig. 6B, lanes 6 and 7 show the results of immunoprecipitations using the amino-terminal eve antibody, and these data are represented schematically in Figure 6A. Strikingly, all fragments examined were isolated in the immunoprecipitation, including ones containing the transcribed region. Furthermore, the yield of each fragment is roughly proportional to its size, with all fragments being cross-linked at $\sim .001 \%$ / $\mathrm{kb}$. Because percentage cross-linking is likely to be directly proportional to occupancy for proteins such as eve that recognize a wide range of sites, our results suggest that eve protein binds in a highly uniform pattern throughout many kilobase pairs of the eve promoter. To provide independent confirmation of this result, crosslinking to the three largest fragments (I, II, and III) was also examined using the carboxy-terminal eve antibody (Fig. 6B, lanes 8,9). The results were the same, except that the yield of each fragment was slightly lower, as expected for this antibody.

The widespread distribution of eve protein on the eve promoter differs from expectations based on previous experiments: Transgenic promoter deletion studies indicate that sequences required for both positive and negative autoregulation lie between -5.2 and $-8 \mathrm{~kb}$ upstream of the RNA start site (Goto et al. 1989; Harding et al. 1989; see Fig. 6A). Importantly, transcription from a promoter containing only the region between $-5.2 \mathrm{~kb}$ and the RNA start site is practically unaffected in eve mutant embryos (Harding et al. 1989). Thus, in the endogenous gene, eve protein binds strongly to a promoter region that has no known eve-dependent regulatory activity when separated from the rest of the promoter. It will now be important to determine whether eve protein is bound at high levels to this isolated promoter construct.

Another striking aspect of our data is that efficient cross-linking occurs on fragments that according to in vitro studies do not contain high affinity binding sites (fragments V and IX, Fig. 6A). This observation may be explained by the finding that in vitro, eve molecules bound to high affinity sites can, through cooperative interactions, cause efficient binding of eve molecules to

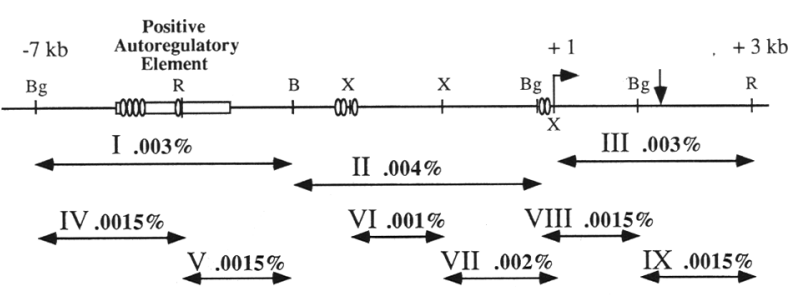

B

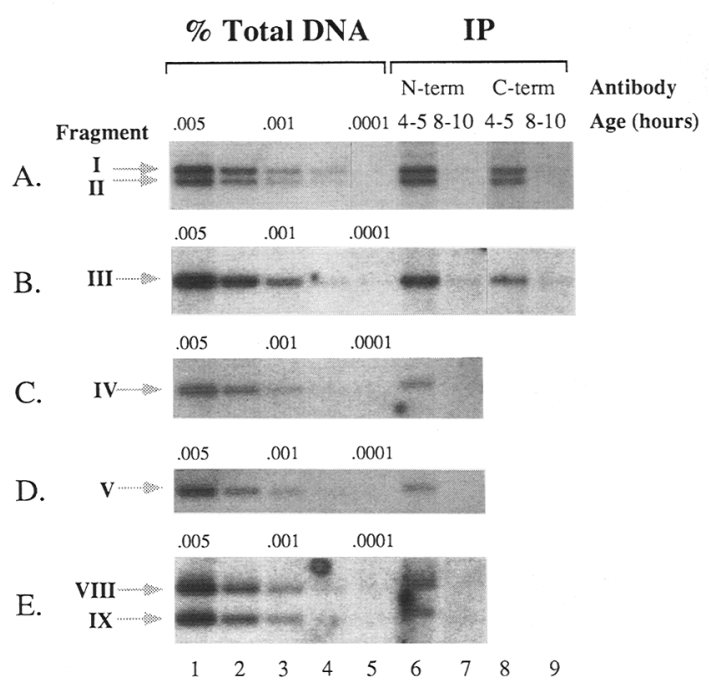

Figure 6. eve protein binds to extensive regions of the eve promoter. (A) Schematic representation of $10 \mathrm{~kb}$ of the eve promoter shows the positive autoregulatory element as an open box (Goto et al. 1989; Harding et al. 1989), the transcription start site as a bent arrow, the polyadenylation site as a vertical arrow, and high affinity eve protein-binding sites determined by in vitro immunoprecipitation and footprinting analysis as open ellipses (Hoey and Levine 1988; Hoey 1989; M. Levine, pers. comm.). Double-headed arrows represent genomic fragments that were assayed for binding by eve protein, with the average level of recovery in UV cross-linking experiments expressed as a percentage of total DNA above each fragment. $(\mathrm{Bg}) \mathrm{Bg} I \mathrm{I} ;(\mathrm{R})$ EcoRI; (B) BamHI; (X) XhoI. (B) UV cross-linking was carried out on 4- to 5-hr (lanes 6,8) and on 8- to 10-hr (lanes 7,9) embryos to determine cross-linking efficiencies to restriction fragments I-IX shown in $A$. Data for fragments VI and VII are not shown. Lanes 1-5 on each blot contain a dilution series of total DNA. In lanes 6 and 7 , the amino-terminal eve antibody was used; in lanes 8 and 9, the carboxy-terminal eve antibody was used. Blot $A$ was probed as in Fig. 4D; B was probed with eve cDNA sequences from an EcoRV-NdeI fragment derived from plasmid pAR3040 eve (Hoey and Levine 1988); C was probed with eve sequences from $-4.7 \mathrm{~kb}$ to $-6.4 \mathrm{~kb}$; $\mathrm{D}$ was probed with the same sequences as $C ; \mathrm{E}$ was probed with the same sequences as $B$.

lower affinity eve sites located at a distance (TenHarmsel et al. 1993). We suggest that such cooperative interactions between eve protein molecules may lead to the filling of many moderate affinity sites in vivo and thus cause the pattern of cross-linking observed on the eve promoter (see Discussion). 
eve protein is detected on promoters not expected to be targets of eve

Cross-linking was also examined on various genes that we did not initially expect to be bound by eve protein in vivo (Fig. 7). Strikingly, low but significant binding by eve protein was detected on all of the following fragments: a 7.3-kb fragment encompassing the rosy gene, two Alcohol dehydrogenase (Adh) fragments spanning the $A d h$ transcription unit, various fragments from the uninduced $h s p 70$ promoter and transcription unit, an $8.7-\mathrm{kb}$ fragment spanning the actin $5 \mathrm{C}$ transcription

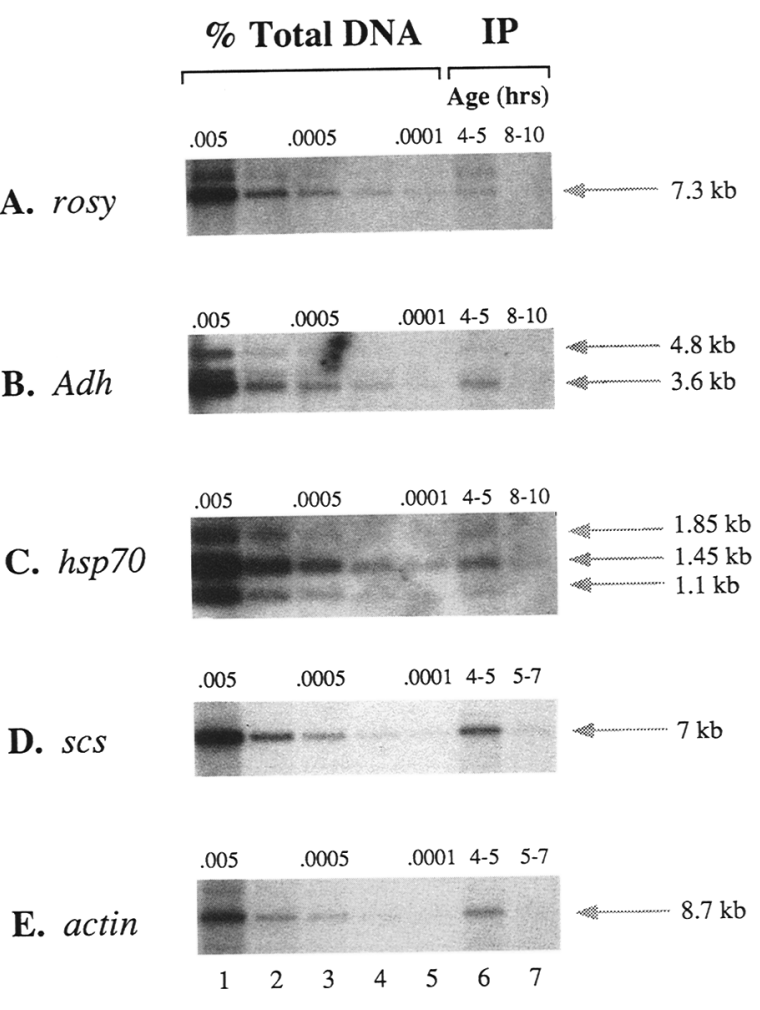

Figure 7. eve protein binds detectably to randomly chosen genes. UV cross-linking was carried out on 4- to 5-hr (lane 6, $A-E$ ), on 8- to 10 -hr (lane $7, A-C$ ), and on 5- to 7-hr (lane 7, D and $E$ | embryos using the amino-terminal eve antibody. Lanes $1-5$ in blots $A-E$ contain a dilution series of total DNA. $(A)$ Chromatin was digested with HindIII and probed as in Fig. 4B, revealing a $7.3-\mathrm{kb}$ genomic rosy fragment. $(B)$ Digested with SalI; the blot was probed with a genomic 4.7- kb EcoRI Adh fragment (plasmid p13E-3; Heberlein et al. 1985) that hybridizes to 4.8 - and $3.6-\mathrm{kb}$ genomic fragments surrounding the RNA start site (Goldberg 1980). The intermediate sized species is a partial digestion product. $(C)$ Digested with BamHI and XhoI and probed with a $2.6-\mathrm{kb} X h o I$ hsp 70 fragment (from plasmid p70X2.6; Rougvie and Lis 1988). The probe hybridizes with three restriction fragments which together contain the transcription units of the five hsp70 genes (Gilmour and Lis 1986). $(D)$ Digested with SalI and probed with a $1.8-\mathrm{kb}$ scs element (Kellum and Schedl 1991) that hybridizes to a $7-\mathrm{kb}$ genomic fragment from the proximal side of the $h s p 7087 \mathrm{~A}$ locus that lies outside of the transcription unit (Udvardy et al. 1985). (E) Digested with EcoRI and probed as in Fig. 4C, revealing an $8.7-\mathrm{kb}$ genomic fragment containing the actin $5 \mathrm{C}$ transcription unit. unit, and a $7-\mathrm{kb}$ fragment containing a putative chromatin domain boundary located several kilobase pairs away from the $h s p 70$ transcribed region (scs, Kellum and Schedl 1991). The average cross-linking per kilobase on these unexpected targets is $.0001 \% / \mathrm{kb}$, or 10 -fold lower than on the eve gene (see also Fig. 10, below); the range is from 26-fold lower on rosy to 6-fold lower on $h s p 70$.

The following considerations argue strongly that the cross-linking signals seen on these genes are eve protein specific: The results were obtained using affinity-purified antibodies, and they are highly reproducible; binding by eve protein on the actin $5 \mathrm{C}$ gene and on the scs element was also detected using the carboxy-terminal eve antibody (data not shown); serum that has been depleted of $e v e$-specific antibodies using affinity chromatography does not precipitate these fragments (data not shown; see also Fig. 5C, lane 5) ruling out the possibility that some genomic regions, when irradiated, have an inherent tendency to be precipitated in this procedure; finally, crosslinking signals follow closely the levels of eve protein expression in development.

Although the significant level of binding on these genes was initially very surprising, we argue in the Discussion that this observation fits previous predictions that the majority of transcription factors not bound to their functional targets would bind randomly at low-levels throughout the rest of the genome (von Hippel et al. 1974; Lin and Riggs 1975). These predictions generally assume that low-level binding throughout the genome involves very low affinity binding to completely random DNA sequences (nonspecific sites). Even if this is the case for eve protein, cross-linking to genes such as rosy is still directly comparable to cross-linking on the eve promoter where many of the eve molecules are almost certainly binding to specific sites. This is because, given similar occupancies, the average cross-linking by transcription factors to specific and nonspecific binding sites is very similar and shows the same rate of increase over a time course of UV irradiation (Lin and Riggs 1974). We therefore interpret the 10-fold lower level of cross-linking to genes such as rosy and actin as a $\sim 10$-fold lower occupancy of $e v e$ protein on these genes.

\section{eve protein also binds throughout the $\mathrm{Ubx}$ and $\mathrm{ftz}$ genes}

Next, we examined binding by eve protein to two other putative eve targets, $U b x$ and $f t z$, to determine whether eve protein binds at high levels to these promoters and, if so, whether the binding is as widespread as on the eve promoter. Previous experiments showed that eve protein can directly repress transcription from the $U b x$ proximal promoter in vitro (Biggin and Tjian 1989b), but eve's repression of $U b x$ in the embryo can also be explained by an indirect mechanism through the engrailed gene (Martinez-Arias and White 1988). Consistent with a direct mechanism of repression, eve protein binds at levels significantly above background to genomic fragments covering $40 \mathrm{~kb}$ of the $U b x$ gene, including the proximal promoter and two enhancers (Fig. 8B; results summarized in 


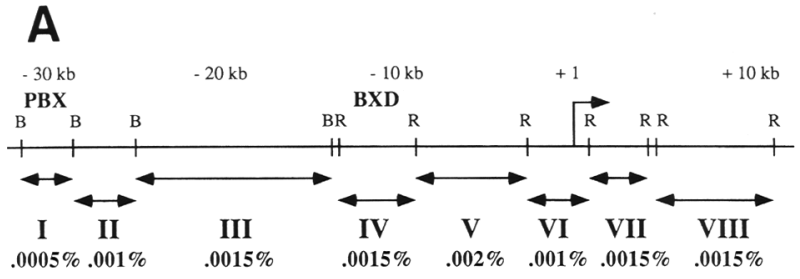

B

A.
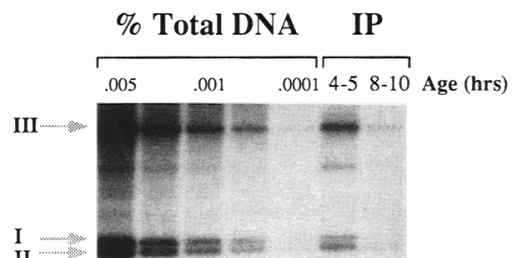

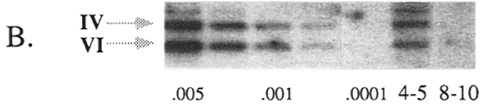
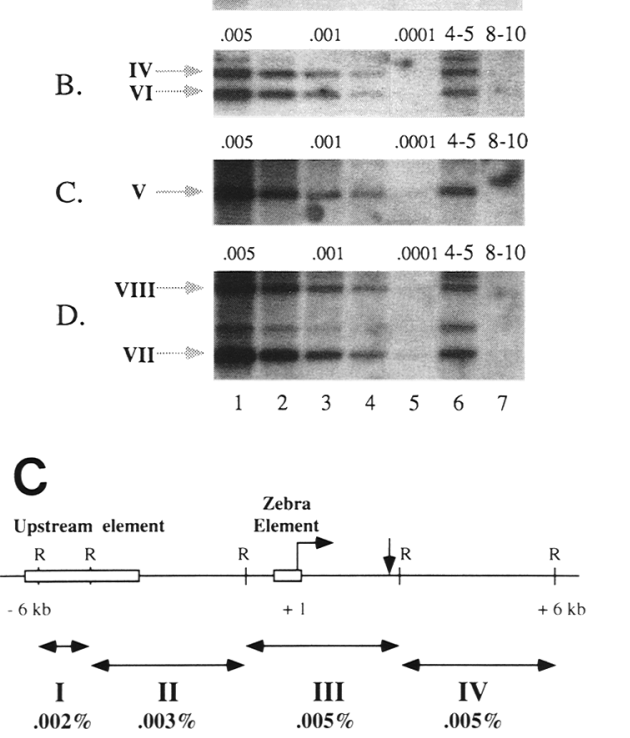

Figure 8. eve protein also cross-links to large regions of the $U b x$ and $f t z$ genes. $(A)$ Schematic representation of the $U b x$ gene similar to the one shown in Fig. 3B; cross-linking by eve protein to each fragment is expressed as a percentage of total DNA. (B) UV cross-linking was carried out on 4- to 5-hr (lane 6) and on 8- to 10-hr (lane 7) embryos using the amino-terminal eve antibody to determine the cross-linking efficiencies to genomic fragments I-VIII shown in $A$. (Lanes 1-5) A dilution series of total DNA. Blot A was probed with $U b x$ genomic fragments 3103 and 3104 (see legend to Fig. 3 (B); Bender et al. 1983); B was probed with 3102 and 3105; C was probed with 3106; D was probed with 3108 and 3109 . Arrows indicate products of complete digestion with restriction enzymes; other bands represent partial digestion products. Partial digestion occurs because of excessive UV exposure; this also explains why partial digestion products are preferentially immunoprecipitated. $(C)$ Schematic diagram of the $f t z$ promoter (derived from Hiromi and Gehring 1987) showing the zebra and upstream enhancer elements and the results of eve protein cross-linking to four genomic fragments spanning this locus. These results were obtained in UV cross-linking experiments on 4- to 5-hr embryos using the amino-terminal eve antibody. Eight to $10-\mathrm{hr}$ embryos served as a negative control.

Fig. 8A). The cross-linking/kb of eve protein on $U b x$ is three- to fourfold lower than on the eve promoter, and about threefold higher than the average on genes such as actin 5C and rosy (see Fig. 7). The level of cross-linking is likely to be significant, as it is consistently higher than the level on rosy and actin 5C for many DNA fragments over a very large region.

We also examined the binding of eve protein to the $f t z$ gene, which it appears to regulate in a largely redundant manner. [Throughout this paper, the term redundant is used to describe a regulatory interaction that is potently occurring in wild-type embryos but that is dispensable because other proteins can perform the same function; (see also Laney and Biggin 1992; Tautz 1992; Rudnicki et al. 1993)]. At the cellular blastoderm stage, eve and $f t z$ proteins are expressed in a series of alternating stripes (Hafen et al. 1984; Harding et al. 1986). Strong loss-offunction mutations in the eve gene cause derepression of $f t z$ transcription in only a small subset of the cells in which eve is normally expressed (Carroll and Scott 1986; Harding et al. 1986). However, ectopic expression of eve protein throughout the embryo at approximately wildtype levels leads to rapid and complete repression of all ftz stripes (Manoukian and Krause 1992). Thus, in wildtype embryos eve may bind to and repress the $f t z$ promoter in all eve-expressing cells, but this function might be redundant with that of other proteins in all but a few cells. In vivo cross-linking in 4- to 5-hr-old embryos shows that eve protein is bound at high levels to four contiguous fragments spanning $12 \mathrm{~kb}$ of the $f t z$ promoter (data not shown; results summarized in Fig. $8 \mathrm{C}$ ). This region includes the upstream $f t z$ autoregulatory element, the "zebra element" required to initiate the striped $f t z$ pattern, and the transcription unit (Hiromi and Gehring 19871 . At $.0013 \%$ cross-linking/kb, the level of crosslinking is slightly higher than on the eve promoter. Therefore, if eve protein were only bound to the $f t z$ promoter in the few cells in which $\mathrm{ftz}$ expression is perturbed by eve loss-of-function mutations, this level of cross-linking would not have been detected. Thus, our data support the idea that eve represses $f t z$ redundantly in many cells.

\section{$\mathrm{ftz}$ protein binds to the same DNA fragments as eve protein in vivo}

We then wanted to examine cross-linking by $f t z$ protein to the same DNA fragments that were assayed for binding by eve molecules. This would allow us to determine whether conditions in the embryo cause these two Q50 homeo domain proteins to bind different sequences, or whether their binding in vivo is largely the same as it is in vitro. In support of the latter possibility, we found that $f t z$ protein binds strongly to the same four $f t z$ promoter fragments that the eve protein occupies at high levels (Figs. 9A and 8C). Although ftz protein cross-links at about twofold lower levels to these fragments than eve protein $(.0007 \% / \mathrm{kb}$ vs. $.00125 \% / \mathrm{kb})$, this difference is observed on virtually all fragments that were assayed for binding by both proteins (see below). The binding of $f t z$ to fragment II of the $f t z$ promoter (Fig. 9A) is of particular interest, as a second site suppression experiment 


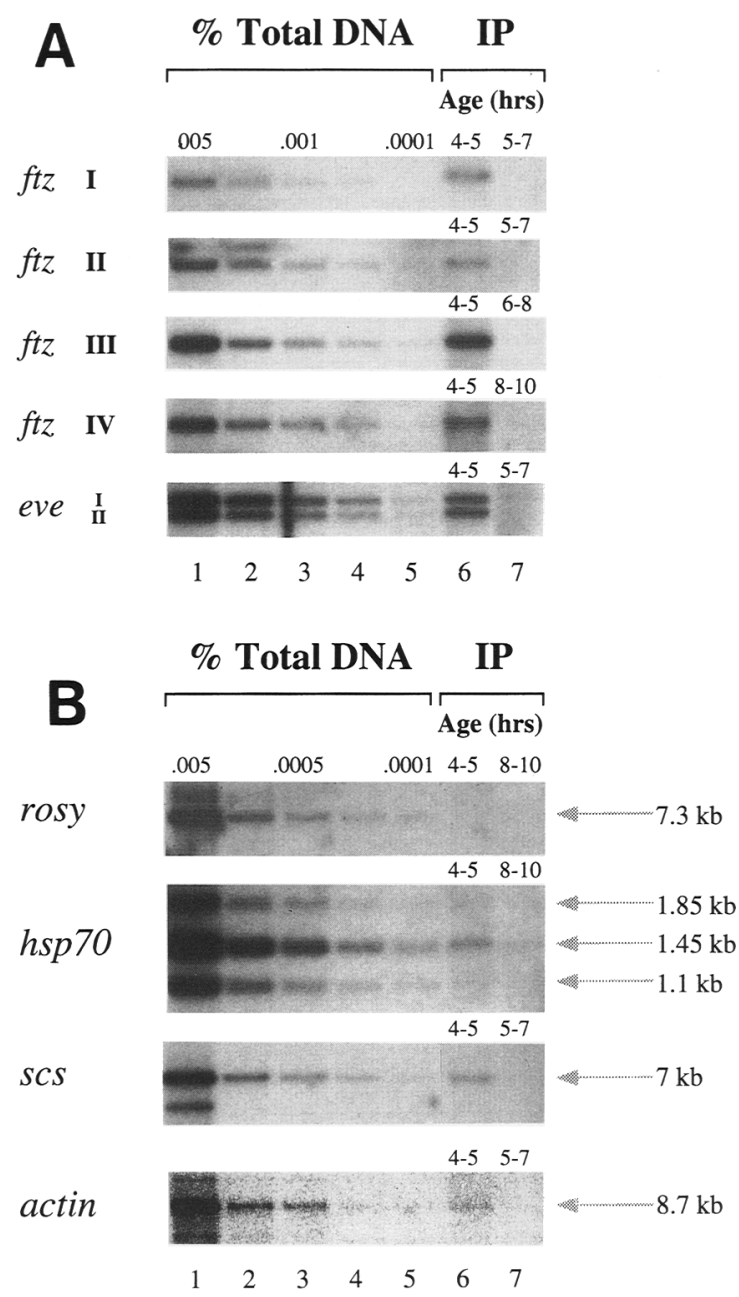

Figure 9. In vivo UV cross-linking by the $f t z$ protein. Crosslinking was carried out on populations of 4- to 5-hr old embryos (lane 6) and on older embryos (lane 7) using affinity-purified anti-ftz antibodies. Like eve protein, $f t z$ expression peaks between 4 and $5 \mathrm{hr}$ after egg laying and then drops sharply, so that older embryos serve as a negative control. Lanes $1-5$ of each blot contain dilution series of total DNA. $(A) \mathrm{ftz}$ protein binds strongly to large portions of the $f t z$ and eve promoters. (ftz I-IV) $f t z$ promoter fragments I-IV shown in Fig. 8C; (eve I,II) eve promoter fragments I and II diagramed in Fig. 6A. Chromatin used in all $\mathrm{ftz}$ blots was digested with EcoRI. Blots $\mathrm{ftz}$ I and $f t z$ II were probed with a $2.8 \mathrm{~kb} B a m \mathrm{HI}-K p n I f t z$ promoter fragment located $5 \mathrm{~kb}$ upstream of the RNA start site; ftz III was probed with a $3.5-\mathrm{kb}$ EcoRI fragment centered around the RNA start site; ftz IV was probed with the next downstream EcoRI fragment $(3.5 \mathrm{~kb})$. All $\mathrm{ftz}$ probes were derived from plasmid pfK 3 , which contains a $12-\mathrm{kb} K p n I$ insert covering the $\mathrm{ftz}$ transcription unit. eve I, II was probed the same as blot $A$ in Fig. 6B. $(B)$ $f t z$ protein binds detectably to randomly chosen promoters. Chromatin was restriction digested and probed exactly as described for the corresponding blots in Fig. 7. The faster migrating fragment in lane 1 of the scs blot is due to a sample of Sall-digested total DNA that was preloaded onto the agarose gel. The actin blot image was obtained using a PhosphorImager.

strongly suggests that $f t z$ protein activates its own expression by binding directly to sequences located in this fragment (Schier and Gehring 1992). Thus, this level of cross-linking is very likely to be functionally significant. Putative $f t z$ autoregulatory sequences are also located in fragment I (Pick et al. 1990), whereas it is not known whether fragments III and IV possess autoregulatory activity. Like the eve protein, the $f t z$ protein also crosslinks strongly to three fragments covering $10 \mathrm{~kb}$ of the eve gene $1.001 \%$ on fragment eve I; $.0015 \%$ on fragment eve $\mathrm{II} ; .0015 \%$ on fragment eve III (Fig. 9A and data not shown; see Fig. 6A for schematic representation of promoter fragments)]. The average cross-linking over this region $(.00045 \% / \mathrm{kb})$ is again $\sim 2.5$-fold lower than the cross-linking by eve protein to the same region. Like the effect of eve on $f t z$, genetic evidence indicates that $f t z$ regulates eve in a redundant fashion (Harding et al. 1986; Kellerman et al. 1990), and our finding that ftz crosslinks strongly to the eve gene is consistent with such a mechanism.

We also determined the level of binding by $\mathrm{ftz}$ protein to genes that are not expected to be regulated by $f t z$. Similar to eve protein, $f t z$ protein was detected at low but significant levels on the hsp $70(.00015 \%)$, scs $(.0004 \%)$, and actin 5C (.0003\%) fragments (Fig. 9B). On the rosy and $A d h$ gene fragments, ftz cross-linking was barely detectable above background levels (Fig. 9B; data not shown). These latter two are also the fragments on which $e v e$ cross-linking/kb was lowest (Figs. 7 and 10). The average cross-linking of $f t z$ protein on the fragments shown in Figure 9B (including $A d h$ ) is $.00003 \% / \mathrm{kb}$ or 20 -fold lower than the average cross-linking to the $f t z$ gene and 14-fold lower than cross-linking to the eve gene (Fig. 9A; data not shown). In summary, like eve, ftz binds at high levels throughout large regions of its genetic targets and at low but significant levels to genes that are not expected to be regulated by $f t z$. Although $e v e$ protein cross-links two- to threefold more strongly to almost all fragments than $f t z$ protein, both proteins cross-link with very similar relative preferences to all 12 fragments on which binding by both was examined (see Fig. 10). Because eve and $f t z$ proteins bind mostly the same sequences in vitro (Biggin and Tjian 1989b), we infer that the similar cross-linking of these proteins to their genetic targets results from both proteins binding the same array of DNA sites in vivo.

\section{Discussion}

We have improved the sensitivity of an in vivo UV crosslinking assay (Gilmour and Lis 1986), so that it is now possible to directly measure DNA binding of sequencespecific transcription factors in living tissue. Using this technique to identify DNA fragments that are bound directly by the Q50 homeo domain proteins eve and $\mathrm{ftz}$ gave three striking results. First, strong binding by these two proteins is detected at remarkably uniform levels throughout the length of their genetically identified target genes. This includes some target genes that appear to be controlled redundantly by these proteins. Second, both proteins are cross-linked on average at only 10- to 20 -fold lower levels to genes that they are generally not 


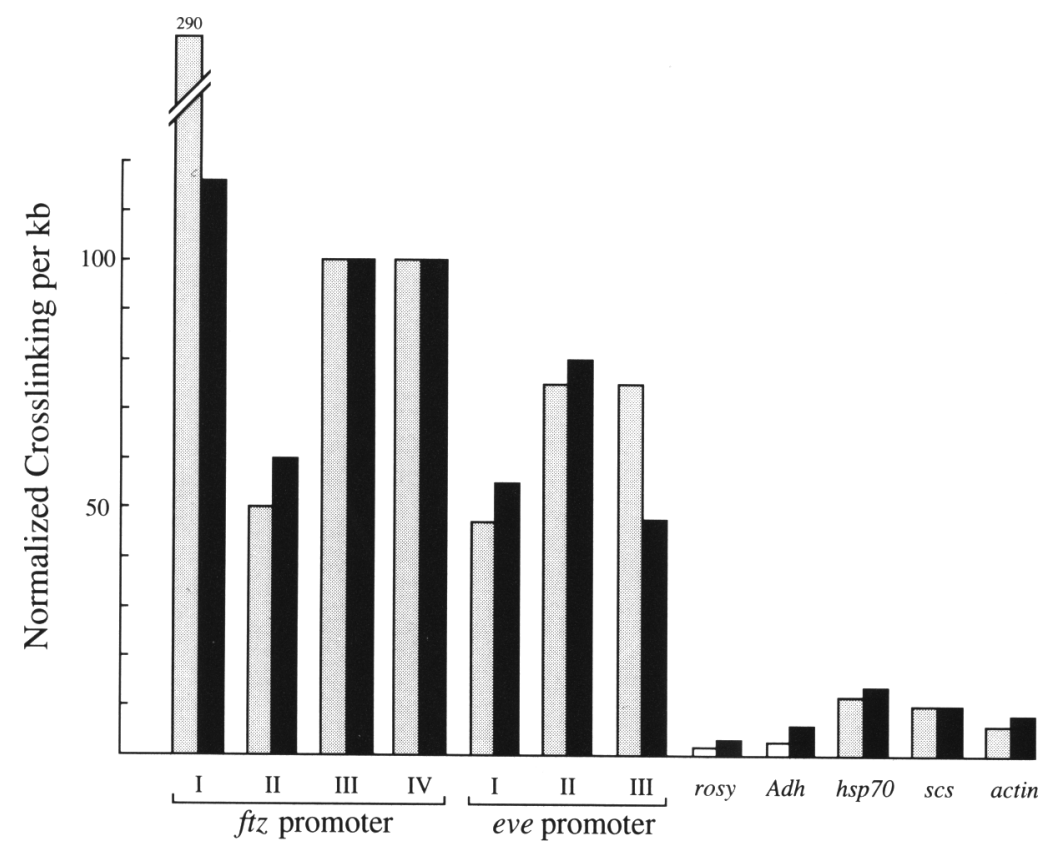

Figure 10. Normalized cross-linking efficiencies of $e v e$ and $f t z$ proteins. To compare the relative preferences of eve and $f t z$ proteins for different DNA fragments, the percent cross-linking of each protein to each fragment was divided by the size of the fragment to give percent cross-linking $/ \mathrm{kb}$. The cross-linking/kb calculated for both eve and $f t z$ proteins on fragment III of the $f t z$ promoter was then arbitrarily assigned a value of 100 . Cross-linking $/ \mathrm{kb}$ of eve and $\mathrm{ftz}$ proteins on all other fragments was expressed on this scale and plotted as shaded ( $f z$ protein) or solid (eve protein) bars on the graph. Because the binding of $f t z$ protein to Adh and rosy was so close to the background, the estimated values for these interactions are somewhat unreliable and are therefore indicated as open bars. expected to regulate, suggesting that $e v e$ and $f t z$ proteins may bind at low levels throughout much of the genome. Third, eve and $f t z$ proteins appear to have the same DNA-binding specificities in vivo, as their relative efficiency of cross-linking to any given DNA fragment is very similar. In contrast, the non-homeo domain transcription factor zeste was found to bind to short DNA elements within a target promoter $(U b x)$, and not to other genes. Below, we discuss mechanisms that can explain the binding of $e v e$ and $f t z$ proteins in vivo, and we suggest that our observations support the view that Q50 homeo domain proteins act by directly regulating largely the same target genes.

\section{Mechanisms of widespread binding by eve and $\mathrm{ftz}$ proteins}

It is generally thought that sequence-specific transcription factors bind to localized regions within the promoters they regulate (Mitchell and Tiian 1989; McKnight and Yamamoto 1992). This was also thought to be the case for Q50 homeo domain proteins because deletion studies indicated that homeo domain responsive promoter elements can be relatively short (e.g., Jiang et al. 1991; Schier and Gehring 1992; Vachon et al. 1992) and because in vitro DNA-binding studies showed preferential binding to certain regions within promoters (Desplan et al. 1985; Beachy et al. 1988; Hoey and Levine 1988; Laughon et al. 1988; Regulski et al. 1991). However, some of the same binding studies also showed that at lower stringency, many more promoter fragments were bound by homeo domain proteins (Desplan et al. 1985; Beachy et al. 1988), indicating the presence of many moderate affinity sites throughout promoters. Our finding that eve and $f t z$ proteins cross-link uniformly throughout their genetic targets suggests that they bind efficiently to these moderate affinity sites in vivo $\left(K_{\mathrm{d}}=10^{-8} \mathrm{M}\right)$ in addition to occupying high affinity sites $\left(K_{\mathrm{d}} \leqslant 10^{-9} \mathrm{M}\right)$. A mechanism for how this could be achieved is suggested by in vitro studies of how eve protein represses the $U b x$ promoter (TenHarmsel et al. 1993). Repression requires the binding of eve protein to moderate affinity sites, and this binding is stabilized by cooperative interactions with other eve molecules bound to distant high affinity sites, causing the intervening DNA to bend. Such cooperativity, which may be a common feature of homeo domain proteins (Beachy et al. 1993), could act to stabilize binding to moderate affinity sites throughout large promoter regions, thereby forming a series of miniloop structures. In this capacity, these proteins may influence profoundly the structure of their target genes and thus may act as chromatin-organizing proteins.

The observation that the eve and ftz proteins crosslink at only $\sim 10$ to 20 -fold lower levels to promoters that they are not expected to regulate is consistent with previous thermodynamic calculations carried out to model the binding of sequence-specific DNA-binding proteins in living cells (von Hippel et al. 1974; Lin and Riggs 1975). Such calculations take into account the specific and nonspecific DNA-binding constants of transcription factors, and the concentration of these proteins and genomic DNA in a cell. They predict that the vast majority of transcription factor molecules not bound to high affinity specific binding sites would bind to the excess of nonspecific DNA sites present in a cell, leaving very little protein free in the nucleoplasm. In the case of a prokaryotic protein such as the $\lambda$ repressor, this would lead to the binding of one repressor molecule every 30 $\mathrm{kb}$. For homeo domain proteins such as eve and $f t z$, 
which are present at 50,000 molecules per cell (Krause et al. 1988; J. Walter, and M.D. Biggin, unpubl.), the same calculations predict a background binding of one molecule every $4 \mathrm{~kb}$ if one disregards potential effects of chromatin structure. We suggest that the detection of lowlevel binding by eve and $f t z$ proteins on genes such as rosy and actin provide direct support for these earlier models. However, we cannot determine whether the background binding by homeo domain proteins is attributable to low affinity interactions with completely random DNA sequences or binding to fortuitously occurring specific sites. The reason for this is that unlike prokaryotic regulators, homeo domain proteins recognize an array of specific DNA sequences that occur quite frequently in nontarget DNAs (Desplan et al. 1985; J. Walter and M.D. Biggin, unpubl.).

By comparison with eve and $f t z$ proteins, the zeste transcription factor does not bind detectably to randomly chosen DNA fragments in vivo. Consistent with this observation, zeste protein discriminates between specific and nonspecific DNA sites in vitro much better than do homeo domain proteins (cf. Benson and Pirrotta 1987, 1988 and Biggin et al. 1988 with Affolter et al. 1990 and Desplan et al. 1985), and the concentration of zeste protein in embryonic nuclei appears to be $\sim 10$-fold lower than that of eve or $\mathrm{ftz}$ (Biggin et al. 1988; Krause et al. 1988). These two properties probably explain why any background binding by zeste protein is below the limit of detection in our assay.

\section{Binding vs. function}

The finding that $e v e$ and $f t z$ proteins bind at low levels to genes such as rosy, $h s p 70$, and actin raises the possibility that these genes could be regulated by eve or $f t z$. However, we suspect that most or all of these interactions are not functional, as eve and $f t z$ probably bind at low levels to thousands of genes throughout the genome, and it is difficult to envision a function for such indiscriminate regulation by homeo domain proteins. We suggest that $e v e$ and $f t z$ proteins may not be able to regulate genes such as rosy and actin because effective regulation may require sequence-specific cofactors that do not bind to rosy and actin, or because binding by $e v e$ and $f t z$ to these genes may be too transient to cause transcriptional regulation. In contrast, we believe the high level of binding throughout genetic targets is likely to be functionally significant, as it is observed with both eve and ftz proteins on all genetic targets examined. This includes a DNA fragment of the $f t z$ promoter that is a strong candidate for direct regulation by $f t z$ protein in vivo (fragment II, Fig. 9A; Schier and Gehring 1992) and other promoter fragments that are considered possible direct targets of eve and/or ftz protein (Biggin and Tjian 1989a; Harding et al. 1989; Pick et al. 1990).

Given the high level binding throughout their target promoters, it is important to note that eve and $f t z$, in some cases, regulate almost wild-type patterns of gene expression when acting through very short regulatory elements in transgenic promoter studies (Goto et al.
1989; Harding et al. 1989; Pick et al. 1990; Müller and Bienz 1992; Schier and Gehring 1992). Also, other large promoter regions from the same genes do not appear to be significantly regulated by eve or $f t z$ in the same type of experiment. An explanation for these observations is that the eve and $f t z$ positive autoregulatory elements contain binding sites for other transcription factors that are also required for enhancer function (Jiang et al 1991; Han et al. 1993; Schier and Gehring 1993). If these cofactors bind only within the autoregulatory element, it would explain why other promoter regions, when isolated from the rest of the gene, are not regulated by these homeo domain proteins. However, we suggest that in the context of intact genes, the binding of homeo domain proteins across the entire promoter may be essential to significantly affect transcription. eve, $f t z$, and other Q50 homeo domain proteins are master regulators that control a wide range of complex promoters in many cell types. In this capacity, they may have to influence the action of a particularly large number of other transcription factors, and binding throughout the length of promoters may be a general mechanism that accomplishes this. In addition, high level binding throughout target genes may serve to communicate the effects of enhancers and silencers to the proximal promoter region or it may have a subtle or redundant role in augmenting the effect of regulatory elements.

\section{Two Q50 homeo domain proteins appear to have the same DNA-binding specificity in vivo}

eve, ftz, engrailed, and the homeotic proteins contain a glutamine at position 50 of the homeo domain (Q50 homeo domain proteins) and bind to largely the same array of DNA sites in vitro (Biggin and Tjian 1989b; Hayashi and Scott 1990). Because we have shown that two of these proteins also have similar DNA-binding specificities in vivo, we conclude that all the members of this group may have the intrinsic ability to bind the same DNA sites in vivo. This has two important implications. First, in those cells of the embryo that coexpress several Q50 homeo domain proteins, competition for DNA sites will probably play an important role in determining how these proteins bind to their targets /see also Desplan et al. 1988; Hoey and Levine 1988; Ohkuma et al. 1990; Lamka et al. 1992). Second, virtually all members of the Q50 family of proteins are uniquely expressed in at least some cells in the embryo; here, the effects of competition can be ignored, and therefore it is likely that these proteins all bind strongly to a common set of target genes. Although in some cases high levels of binding may be nonfunctional, in general we believe this will not be the case, and we favor the view that different Q50 homeo domain proteins regulate predominantly the same target genes (for similar models, see Garcia-Bellido 1975; Lawrence 1992). If this is true, the chief differences between Q50 homeo domain proteins would lie in the degree to which they activate or repress the same genes. Presumably, such differences would arise through their differential interactions with the unique combinations 
of other transcription factors that are known to bind to these target genes (Biggin and Tjian 1989b; Ohkuma et al. 1990; Han et al. 1993; TenHarmsel et al. 1993) and also with proteins that may not directly contact DNA themselves (Tanaka et al. 1988; Mendel et al. 1991).

Genetic experiments provide at least partial support for the above model, as mutations in different Q50 homeo domain genes frequently lead to altered expression of the same downstream genes /Garcia-Bellido 1975; Harding et al. 1986; Akam 1987; Frasch et al. 1988; Gould and White 1992; Lawrence 1992; Capovilla et al. 1994). However, in some instances, expression of a gene downstream of one homeo domain gene is not affected by mutations in other Q50 homeo domain genes (e.g., see Harding et al. 1986; Hayashi and Scott 1990). We suggest that many of these latter instances can be explained if some targets are regulated redundantly by some homeo domain proteins. For example, we have shown that eve and $f t z$ proteins bind at high levels to genes whose expression is not significantly affected by loss-of-function mutations in eve or $f t z$, and in the Results section we detail the evidence that these interactions are functional and redundant, rather than nonfunctional. Thus, if one takes redundancy into account, the available genetic evidence in no way contradicts the view that Q50 homeo domain proteins largely regulate the same targets.

\section{Materials and methods}

\section{Antibodies}

Using standard techniques, the amino-terminal eve antibody was affintiy purified from a polyclonal rabbit serum directed against amino acids 1-246 of the eve protein (M. Frasch, pers. comm.), and the carboxy-terminal eve antibody was affinity purified from a polyclonal guinea pig serum directed against amino acids 238-376 of eve (R. Warrior, pers. comm.). Both crude sera give the characteristic seven-stripe eve expression pattern in whole mount antibody staining of embryos (Stanojevic et al. 1989, Manoukian and Krause 1992). Affinity-purified rabbit anti-zeste antibodies are directed against the carboxy-terminal region of the zeste protein (region III; Benson and Pirrotta 1987, 1988; Bickel 1991). $\mathrm{ftz}$ antibodies were affinity purified from a polyclonal rabbit serum raised against wild-type $f t z$ protein; the affinity-purified antibodies give the canonical $f t z$ pair-rule pattern with low background in whole mount antibody staining of embryos (S. Carroll, pers. comm.).

\section{Embryo irradiation and chromatin isolation}

The original UV cross-linking procedure (Gilmour and Lis 1985 1986; Rougvie 1989) was designed to study RNA polymerase, which cross-links to DNA $\sim 100$-fold more efficiently than sequence-specific transcription factors (J. Walter and M.D. Biggin, unpubl.). This is probably because RNA polymerase interacts with single-stranded DNA, a much better substrate for UV cross-linking. To detect DNA binding by sequence-specific factors, many changes to the original cross-linking protocol were made, and those that significantly improved the sensitivity of the method are indicated below. All experiments were performed at least twice, but most experiments were repeated three to five times, and the variability in yields of immunoprecipitated DNA fragments rarely exceeded $25 \%$.
Embryos were collected for 1 or $2 \mathrm{hr}$ from population cages of adult flies maintained at $60 \%$ humidity and $24.5^{\circ} \mathrm{C}$ and then aged for the desired time at $24.5^{\circ} \mathrm{C}$. The embryos were weighed, dechorionated in fresh $50 \%$ Clorox bleach to increase UV exposure, and resuspended in ice-cold $0.1 \%$ Tween 20 . Aliquots of embryos (2-5 grams) were irradiated at $4^{\circ} \mathrm{C}$ using a Fotodyne DNA transfer lamp with four $15 \mathrm{~W}$ bulbs generating $254 \mathrm{~nm}$ light. The embryo suspension was placed at a distance of $3 \mathrm{~cm}$ from the bulbs, irradiated for $30 \mathrm{~min}$ with periodic shaking, and frozen immediately in liquid nitrogen.

Embryos (8-10 grams) were partially thawed, homogenized in $30 \mathrm{ml}$ of cold NIB buffer $10.3 \mathrm{M}$ sucrose, $15 \mathrm{~mm} \mathrm{NaCl}, 5 \mathrm{~mm}$ $\mathrm{MgCl}_{2}, 15 \mathrm{~mm}$ Tris at $\mathrm{pH} 7.5,60 \mathrm{~mm} \mathrm{KCl}, 0.1 \mathrm{~mm}$ EDTA, 0.1 mM EGTA/ with three strokes of a motorized B Dounce homogenizer at $800 \mathrm{rpm}$, and filtered through Miracloth (Calbiochem). While being stirred, $20 \%$ Triton X-100 was added to a final concentration of $0.3 \%$ and the suspension was centrifuged at $4000 \mathrm{rpm}$ and $4^{\circ} \mathrm{C}$ for $15 \mathrm{~min}$ in a Sorvall SS34 rotor (Beckman) to pellet nuclei. Nuclei were resuspended in nuclei lysis buffer (100 mM NaCl, $10 \mathrm{~mm}$ Tris at $\mathrm{pH} 8.0,1 \mathrm{~mm}$ EDTA, 0.1\% NP-40, $0.5 \mathrm{~mm}$ phenlymethylsulfonyl fluoride) by manual homogenization in a B Dounce homogenizer, $1 / 10$ volume of $20 \%$ Sarkosyl was added to lyse nuclei, and the chromatin was sheared by one passage through an 18-gauge needle and two passages through a 25-gauge needle. Sheared chromatin from up to 23 grams of 4- to 5-hr embryos and up to 7.5 grams of 8 - to 10 -hr embryos in a volume of $9 \mathrm{ml}$ was purified on 26- $\mathrm{ml} \mathrm{CsCl}$ step gradients (Gilmour and Lis 1985). Chromatin was harvested from the gradient by insertion of an 18-gauge needle near the bottom of the tube and collection of 1 -ml fractions. Peak fractions were pooled and dialyzed for $7 \mathrm{hr}$ against three changes of dialysis buffer $(2 \mathrm{mM}$ EDTA, $50 \mathrm{mM}$ Tris at $\mathrm{pH} 8.01$. Chromatin yields are $200 \mu \mathrm{g} /$ gram of 4- to 5-hr embryos, $500 \mu \mathrm{g} / \mathrm{gram}$ of 5- to 7 -hr embryos, and $800 \mu \mathrm{g} / \mathrm{gram}$ of $8-$ to $10-\mathrm{hr}$ embryos. Dialyzed chromatin is frozen in liquid nitrogen and stored at $-70^{\circ} \mathrm{C}$ where it remains stable for months.

\section{Chromatin digestion and immunoprecipitation}

For digestion with restriction endonucleases, chromatin was supplemented to contain final concentrations of $150 \mathrm{~mm} \mathrm{NaCl}$, $10 \mathrm{~mm}$ Tris at $\mathrm{pH} 7.5,10 \mathrm{~mm} \mathrm{MgCl}_{2}, 50 \mu \mathrm{g} / \mathrm{ml}$ of RIA grade BSA, and $.01 \%$ Triton X-100. Aliquots of $450 \mu \mathrm{g}$ of chromatin were prewarmed for $15 \mathrm{~min}$ at $37^{\circ} \mathrm{C}$ and then restriction digested with two additions of 100 units of enzyme over $12 \mathrm{hr}$. For the last $2 \mathrm{hr}$ of the digestion, RNase was added to $60 \mu \mathrm{g} / \mathrm{ml}$. The digests were stopped by the addition of $1 / 25$ volume of $0.5 \mathrm{M}$ EDTA. Sarkosyl was added to a final concentration of $.05 \%$ and Triton-X 100 to a final concentration of $0.3 \%$. The chromatin was centrifuged for $15 \mathrm{~min}$ in a microcentrifuge at $4^{\circ} \mathrm{C}$ and transferred to fresh tubes. The appropriate affinity purified primary antibody $(1-2 \mu \mathrm{g})$ was added (except in the experiment shown in Fig. 5D, where $1 \mu$ l of crude serum against eve residues 1-246 was used), and the mixture was rocked for $3 \mathrm{hr}$ at $4^{\circ} \mathrm{C}$ and then centrifuged again for $15 \mathrm{~min}$ at $4^{\circ} \mathrm{C}$. The supernatants were individually passed through $0.22-\mu \mathrm{m}$ syringe filters directly into fresh tubes to remove nonspecifically precipitated chromatin. Twenty-five microliters of a $20 \%$ suspension of Staphylococcus aureus (Staph A) cells (see below) was added to each reaction and incubated for no more than $15 \mathrm{~min}$ at room temperature; longer incubations contribute to nonspecific backgrounds. Staph A cells were pelleted and washed twice in $1.4 \mathrm{ml}$ of dialysis buffer containing $0.2 \%$ Sarkosyl, and four times in $1.4 \mathrm{ml}$ of immunoprecipitation buffer (100 $\mathrm{mm}$ Tris at $\mathrm{pH} 9.0$, $500 \mathrm{~mm} \mathrm{LiCl}, 1 \% \mathrm{NP}-40,1 \%$ deoxycholic acid). Washes were carried out at room temperature, and during the last wash, the 
Staph A cells were transferred to fresh tubes to remove chromatin stuck to plastic. Immune complexes were eluted from Staph A cells by vortexing the cells for $10 \mathrm{~min}$ in $100 \mu \mathrm{l}$ of elution buffer $(50 \mathrm{~mm} \mathrm{NaHCO}, 1 \%$ SDS, $1.5 \mu \mathrm{g} / \mathrm{ml}$ of sonicated calf thymus DNA at pH10), spinning down cells, and harvesting the supernatant. This was repeated two more times. The eluted DNA was mixed with $200 \mu \mathrm{l}$ of $0.3 \%$ SDS, $50 \mathrm{~mm}$ Tris at $\mathrm{pH} 7.5,10 \mathrm{~mm}$ EDTA, and $1 \mathrm{mg} / \mathrm{ml}$ of proteinase $\mathrm{K}$ (added fresh) and incubated at $60^{\circ} \mathrm{C}$ for $12 \mathrm{hr}$, after which it was precipitated by the addition of $50 \mu \mathrm{l}$ of $3 \mathrm{M}$ sodium acetate (pH 5.3), $40 \mu \mathrm{g}$ of yeast carrier RNA, and $1.25 \mathrm{ml}$ of ethanol.

Staph A cells were prepared as follows to reduce nonspecific adsorption of chromatin: Lyophilized Staph A cells (Boehringer Mannheim) were resuspended as a 5\% solution in PBS, $3 \%$ SDS, and $10 \% \beta$-mercaptoethanol and boiled for $30 \mathrm{~min}$. After washing, they were resuspended as a $5 \%$ suspension in chromatin purified from irradiated 8- to 10-hr-old embryos that had been sonicated to an average length of $2 \mathrm{~kb}$. The cells were rocked for $3 \mathrm{hr}$ at $4^{\circ} \mathrm{C}$, spun down, and resuspended as a $20 \%$ solution in dialysis buffer containing $0.2 \%$ Sarkosyl.

\section{UV cross-linking on tissue culture cells}

Unless specified otherwise, the procedure was the same as for embryos. Schneider line 2 cells $\left(8 \times 10^{7}\right.$; Schneider 1972) were transfected by the calcium phosphate method (DiNocera and Dawid 1983) as described previously (Biggin and Tjian 1989a). Twenty-four micrograms of pUbx CAT $-600 /+360$ and either $16 \mu \mathrm{g}$ of pPac $\mathrm{U}+N d e \mathrm{I}$ or $16 \mu \mathrm{g}$ of pPac $\mathrm{U}+N$ del eve (Biggin and Tjian 1989a) were added to the cells. After $48 \mathrm{hr}$, cells were mixed with $1 / 500$ volume of $12 \% \mathrm{HCl}$ to dissolve calcium phosphate precipitates, pelleted, washed in 0.7 volumes of $137 \mathrm{~mm}$ $\mathrm{NaCl}, 2.7 \mathrm{~mm} \mathrm{KCl}$, and $5 \mathrm{~mm}$ bisTris ( $\mathrm{pH} 6.0$ ), pelleted again, and resuspended in 1 volume of cold PBS. Cells $\left(2.4 \times 10^{8}\right.$ were irradiated using the same arrangement as for embryos except that irradiation was for $4 \mathrm{~min}$. After irradiation, the cells were spun down and resuspended in $2.7 \mathrm{ml}$ of nuclei lysis buffer. Cells were lysed with $300 \mu \mathrm{l}$ of $20 \%$ Sarkosyl, and the chromatin was sheared by five passages through a 25 -gauge needle and loaded onto an $8.3-\mathrm{ml} \mathrm{CsCl}$ step gradient $14.5 \mathrm{ml}$ of $1.75 \mathrm{~g} / \mathrm{ml}$ $\mathrm{CsCl}, 2.3 \mathrm{ml} 1.5 \mathrm{~g} / \mathrm{ml} \mathrm{CsCl}, 1.5 \mathrm{ml} 1.3 \mathrm{~g} / \mathrm{ml} \mathrm{CsCl}$. Gradients were centrifuged for $36 \mathrm{hr}$ at $37,000 \mathrm{rpm}$ and $20^{\circ} \mathrm{C}$ in a Beckman SW41 rotor. Each immunoprecipitation was carried out with chromatin from $4 \times 10^{7}$ cells essentially as described above.

\section{Southern blotting}

Because of the small amounts of DNA being detected and the large quantities of carrier DNA used to purify immunoprecipitates, it was essential to employ this Southern blotting protocol, which gives high signals and low backgrounds. DNA was separated on a $0.7 \%$ agarose gel, denatured in $1.5 \mathrm{M} \mathrm{NaCl}, 0.5 \mathrm{M}$ $\mathrm{NaOH}$ for $30 \mathrm{~min}$, neutralized in $1.5 \mathrm{M} \mathrm{NaCl}, 0.5 \mathrm{M}$ Tris at $\mathrm{pH}$ 7.2, $1 \mathrm{~mm}$ EDTA for $30 \mathrm{~min}$, and transferred to Hybond-N (Amersham, uncharged nylon membrane) for $12 \mathrm{hr}$ using capillary transfer in $20 \times$ SSPE $\left(3.6 \mathrm{M} \mathrm{NaCl}, 0.2 \mathrm{M} \mathrm{NaPO}_{4}, 20 \mathrm{~mm}\right.$ EDTA at $\mathrm{pH} 8.01$. After transfer, membranes were washed for $5 \mathrm{~min}$ in $2 \times$ SSPE, gently blotted dry, baked for $30 \mathrm{~min}$ at $80^{\circ} \mathrm{C}$ in a vacuum oven, and irradiated for 5-30 sec /depending on the batch of membrane/ with a Fotodyne DNA transfer lamp. The membrane was then incubated for $16-24 \mathrm{hr}$ at $42^{\circ} \mathrm{C}$ in prehybridization solution $150 \%$ formamide, $6 \times \mathrm{SSPE}, 90 \mu \mathrm{g} / \mathrm{ml}$ of sonicated calf thymus DNA, half of which had been denatured by boiling, $10 \mu \mathrm{g} / \mathrm{ml}$ of sheared Escherichia coli DNA, $5 \times$ Denhardt's solution, $10 \%$ dextran sulfate, $5 \%$ SDS, $1 \%$ Sarkosyl; filter through $0.45-\mu \mathrm{m}$ syringe filter). Radioactive probe with a sp. act. of $\sim 5 \times 10^{9} \mathrm{cpm} / \mu \mathrm{g}$ (generated by random priming using an Amersham kit) was added to the blot at $1.6 \times 10^{7} \mathrm{cpm} / \mathrm{ml}$ of hybridization solution and hybridized for $20 \mathrm{hr}$. Blots were washed for $30 \mathrm{~min}$ in $2 \times \mathrm{SSPE}, 0.1 \% \mathrm{SDS}$, at room temperature, for $15 \mathrm{~min}$ in $1 \times \mathrm{SSPE}, 0.1 \% \mathrm{SDS}$, at $65^{\circ} \mathrm{C}$, for $4-24 \mathrm{hr}$ in $0.1 \times$ SSPE and $1.0 \%$ SDS, at $65^{\circ} \mathrm{C}$ and exposed to film once the filter background dropped below 1 count per second. A 4- to 5-day exposure was typically required to detect $.0001 \%$ of total DNA in a reaction originally containing $450 \mu \mathrm{g}$ of chromatin.

A more detailed protocol is available upon request.

\section{Acknowledgments}

We are grateful to Manfred Frasch, Rahul Warrior, Sean Carroll, Arno Greenleaf, and Vincent Pirrotta for their generous gifts of antibodies. We thank Michael Levine for useful discussions and are especially grateful to John Lis and Ann Rougvie for their help during the early stages of this project. We thank Trevor Williams, Bill Segraves, Bill McGinnis, Cornelius Gross, and the members of our laboratory for critical readings of this manuscript. This work was funded in part by a grant from the National Institutes of Health to M.D.B. and also by Pew and Searle scholarships to M.D.B.

The publication costs of this article were defrayed in part by payment of page charges. This article must therefore be hereby marked "advertisement" in accordance with 18 USC section 1734 solely to indicate this fact.

\section{References}

Affolter, M., A. Percival-Smith, M. Müller, W. Leupin, and W.J. Gehring. 1990. DNA binding properties of the purified Antennapedia homeo domain. Proc. Natl. Acad. Sci. 87: 40934097.

Akam, M.E. 1987. The molecular basis for metameric pattern in the Drosophila embryo. Development 101: 1-22.

Appel, B. and S. Sakonju. 1993. Cell-type-specific mechanisms of transcriptional repression by the homeotic gene products UBX and ABD-A in Drosophila embryos. EMBO J. 12: 10991109.

Beachy, P.A., M.A. Krasnow, E.R. Gavis, and D.S. Hogness. 1988. An Ultrabithorax protein binds sequences near its own and the Antennapedia P1 promoters. Cell 55: 1069-1081.

Beachy, P.A., J. Varkey, K.E. Young, D.P. von Kessler, B.I. Sun, and S.C. Ekker. 1993. Cooperative binding of an Ultrabithorax homeodomain protein to nearby and distant DNA sites. Mol. Cell. Biol. 13: 6941-6956.

Bender, W., M. Akam, F. Karch, P.A. Beachy, M. Peifer, P. Spierer, E.B. Lewis, and D.S. Hogness. 1983. Molecular genetics of the bithorax complex in Drosophila melanogaster. Science 221: 23-29.

Benson, M. and V. Pirrotta. 1987. The product of the Drosophila zeste gene binds to specific DNA sequences in white and Ubx. EMBO I. 6: 1387-1392.

- 1988. The Drosophila zeste protein binds cooperatively to sites in many gene regulatory regions: Implications for transvection and gene regulation. EMBO I. 7: 3907-3915.

Bickel, S.E. 1991. "Properties of the Drosophila Zeste protein and analysis of mutant Zeste polypeptides." Ph.D. thesis, Baylor College of Medicine, Houston, Texas.

Biggin, M.D. and R. Tijan. 1989a. A purified Drosophila homeodomain protein represses transcription in vitro. Cell 58: $533-440$.

- $1989 \mathrm{~b}$. Transcription factors and the control of Drosophila development. Trends Genet. 5: 377-383.

Biggin, M.D., S.E. Bickel, M. Benson, V. Pirrotta, and R. Tjian. 1988. zeste encodes a sequence-specific transcription factor 
that activates the Ultrabithorax promoter in vitro. Cell 53: 713-722.

Blatter, E.E., Y.W. Ebright, and R.H. Ebright. 1992. Identification of an amino acid base contact in the GCN4-DNA complex by bromouracil-mediated photocross-linking. Nature 359: 650-652.

Campos-Ortega, J. and V. Hartenstein. 1985. The embryonic development of Drosophila melanogaster. Springer-Verlag, Berlin, Germany.

Capovilla, M., M. Brandt, and J. Botas. 1994. Direct regulation of decapentaplegic by Ultrabithorax and its role in Drosophila midgut morphogenesis. Cell 76: 461-475.

Carroll, S.B. and M.P. Scott. 1986. Zygotically active genes that affect the spatial expression of the fushi tarazu segmentation gene during early Drosophila embryogenesis. Cell 45: 113-126.

Champlin, D.T., M. Frasch, H. Saumweber, and J.T. Lis. 1991. Characterization of a Drosophila protein associated with boundaries of transcriptionally active chromatin. Genes \& Dev. 5: 1611-1621.

Cohen, S.M. 1990. Specification of limb development in the Drosophila embryo by positional cues from segmentation genes. Nature 343: 173-177.

Coté, B., W. Bender, D. Curtis, and A. Chovnick. 1986. Molecular mapping of the rosy locus of Drosophila melanogaster. Genet. Soc. Am. 112: 769-783.

Desplan, C., J. Theis, and P.H. O'Farrell. 1985. The Drosophila developmental gene engrailed encodes a sequence specific DNA binding activity. Nature 318: 630-635.

- 1988. The sequence specificity of homeo domain-DNA interaction. Cell 54: 1081-1090.

Dessain, S., C. Gross, M.A. Kuziora, and W. McGinnis. 1992. Antp-type homeo domains have distinct DNA binding specificities that correlate with their different regulatory functions in embryos. EMBO I. 11: 991-1002.

DiNocera, P.P. and I.B. Dawid. 1983. Transient expression of genes introduced into cultured cells of Drosophila. Proc. Natl. Acad. Sci. 80: 7095-7098.

Ekker, S.C., D.P. von Kessler, and P.A. Beachy. 1992. Differential DNA sequence recognition is a determinant of specificity in homeotic gene action. EMBO $/$. 11: 4059-4072.

Frasch, M., T. Hoey, C. Rushlow, H. Doyle, and M. Levine. 1987. Characterization and localization of the even-skipped protein of Drosophila. EMBO /. 6: 749-759.

Frasch, M., R. Warrior, J. Tugwood, and M. Levine. 1988. Molecular analysis of even-skipped mutants in Drosophila development. Genes \& Dev. 2: 1824-1838.

Fyrberg, E.A., K.L. Kindle, and N. Davidson. 1980. The actin genes of Drosophila: A dispersed multigene family. Cell 19: 365-378.

Garcia-Bellido, A.G. 1975. Genetic control of wing disk development in Drosophila. Cell patterning. Ciba Found. Symp. 29: 161-178.

Giardina, C., M. Pérez-Riba, and J.T. Lis. 1992. Promoter melting and TFIID complexes on Drosophila genes in vivo. Genes \& Dev. 6: 2190-2200.

Gilmour, D.S. and J.T. Lis. 1985. In vivo interactions of RNA polymerase II with genes of Drosophila melanogaster. Mol. Cell. Biol. 5: 2009-2018.

- 1986. RNA polymerase II interacts with the promoter region of the noninduced hsp 70 gene in Drosophila melanogaster cells. Mol. Cell. Biol. 6: 3984-3989.

Gilmour, D.S., G. Pflugfelder, J.C. Wang, and J.T. Lis. 1986. Topoisomerase I interacts with transcribed regions in Drosophila cells. Cell 44: 401-407.

Goldberg, D.A. 1980. Isolation and partial characterization of the Drosophila alcohol dehydrogenase gene. Proc. Natl. Acad. Sci. 77: 5794-5798.

Goto, T., P. Macdonald, and T. Maniatis. 1989. Early and late periodic patterns of even skipped expression are controlled by distinct regulatory elements that respond to different spatial cues. Cell 57: 413-422.

Gould, A. and R.A.H. White. 1992. Connectin, a target of homeotic gene control in Drosophila. Development 116: 11631174.

Hafen, E., A. Kuroiwa, and W.J. Gehring. 1984. Spatial distribution of transcripts from the segmentation gene fushi-tarazu during Drosophila embryonic development. Cell 37: 833841.

Han, W., Y. Yu, N. Altan, and L. Pick. 1993. Multiple proteins interact with the fushi-tarazu proximal enhancer. Mol. Cell. Biol. 13: 5549-5559.

Hanes, S.D. and R. Brent. 1989. DNA specificity of the bicoid activator protein is determined by homeodomain recognition helix residue 9. Cell 57: 1275-1283.

Harding, K., C. Rushlow, H.J. Doyle, T. Hoey, and M. Levine. 1986. Cross-regulatory interactions among pair-rule genes in Drosophila. Science 233: 953-959.

Harding, K., T. Hoey, R. Warrior, and M. Levine. 1989. Autoregulatory and gap gene response elements of the evenskipped promoter of Drosophila. EMBO J. 8: 1205-1212.

Hayashi, S. and M.P. Scott. 1990. What determines the specificity of action of Drosophila homeo domain proteins? Cell 63: 883-894.

Heberlein, U., B. England, and R. Tjian. 1985. Characterization of Drosophila transcription factors that activate the tandem promoters of the alcohol dehydrogenase gene. Cell 41: 965977.

Hiromi, Y. and W.J. Gehring. 1987. Regulation and function of the Drosophila segmentation gene fushi tarazu. Cell 50: 963-974.

Hockensmith, J.W., W.L. Kubasek, W.R. Vorachek, E.M. Evertsz, and P.H. von Hippel. 1991. Laser cross-linking of protein-nucleic acid complexes. Methods Enzymol. 208: 211-235.

Hoey, T. 1989. "DNA binding properties of Drosophila homeobox proteins." Ph.D. thesis, Columbia University, New York.

Hoey, T. and M. Levine. 1988. Divergent homeo box proteins recognize similar DNA sequences in Drosophila. Nature 332: 858-861.

Immerglück, K., P.A. Lawrence, and M. Bienz. 1990. Induction across germ layers in Drosophila mediated by a genetic cascade. Cell 62: 261-268.

Jiang, J., T. Hoey, and M. Levine. 1991. Autoregulation of a segmentation gene in Drosophila: Combinatorial interaction of the even-skipped homeo box protein with the distal enhancer element. Genes \& Dev. 5: 265-277.

Kellerman, K.A., D. Mattson, and I. Duncan. 1990. Mutations affecting the stability of the fushi-tarazu protein of Drosophila. Genes \& Dev. 4: 1936-1950.

Kellum, R. and P. Schedl. 1991. A position-effect assay for boundaries of higher order chromosomal domains. Cell 64: 941-950.

Krause, H.M., R. Klemenz, and W.J. Gehring. 1988. Expression, modification and localization of the fushi tarazu protein in Drosophila embryos. Genes \& Dev. 2: 1021-1036.

Lamka, M.L., A. Boulet, and S. Sakonju. 1992. Ectopic expression of UBX and ABD-B proteins during Drosophila embryogenesis: Competition, not a functional hierarchy, explains phenotypic suppression. Development 116: 841-854.

Laney, J.D. and M.D. Biggin. 1992. zeste, a nonessential gene, 
potently activates Ultrabithorax transcription in the Drosophila embryo. Genes \& Dev. 6: 1531-1541.

Laughon, A., W. Howell, and M. Scott. 1988. The interaction of proteins encoded by Drosophila homeotic and segmentation genes with specific DNA sequences. Development (Suppl.) 104: 75-83.

Lawrence, P. 1992. The making of a fly. Blackwell Scientific Publications, Oxford, England.

Lewis, E.B. 1978. A gene complex controlling segmentation in Drosophila. Nature 88: 225-239.

Lin, S. and A.D. Riggs. 1974. Photochemical attachment of lac repressor to bromodeoxyuridine-substituted lac operator by ultraviolet irradiation. Proc. Natl. Acad. Sci. 71: 947-951.

. 1975. The general affinity of lac repressor for E. coli DNA: Implications for gene regulation in procaryotes and eucaryotes. Cell 4: 107-111.

Manoukian, A.S. and H.M. Krause. 1992. Concentration-dependent activities of the even-skipped protein in Drosophila embryos. Genes \& Dev. 6: 1740-1751.

Martinez-Arias, A. and R.A.H. White. 1988. Ultrabithorax and engrailed expression in Drosophila embryos mutant for segmentation genes of the pair-rule class. Development 102: 325-338.

McGinnis, W., R.L. Garber, J. Wirz, A. Kuroiwa, and W.J. Gehring. 1984. A homologous protein coding sequence in Drosophila homeotic genes and its conservation in other metazoans. Cell 37: 403-408.

McKnight, S.L. and K.R. Yamamoto, eds. 1992. Transcriptional regulation. Cold Spring Harbor Laboratory Press, Cold Spring Harbor, New York.

Mendel, D.B., P.A. Khavari, P.B. Conley, M.K. Graves, L.P. Hansen, A. Admon, and G.R. Crabtree. 1991. Characterization of a cofactor that regulates dimerization of a mammalian homeodomain protein. Science 254: 1762-1767.

Mismer, D. and G.M. Rubin. 1987. Analysis of the promoter of the ninaE opsin gene in Drosophila melanogaster. Genetics 46: $565-578$.

Mitchell, P.A. and R. Tjian. 1989. Transcriptional regulation in mammalian cells by sequence-specific DNA binding proteins. Science 245: 371-378.

Müller, J. and M. Bienz. 1991. Long range repression conferring boundaries of Ultrabithorax expression in the Drosophila embryo. EMBO /. 10: 3147-3155.

- 1992. Sharp anterior boundary of homeotic gene expression conferred by the fushi-tarazu protein. EMBO J. 11: 3653-3661.

Nüsslein-Volhard, C. and E. Wieschaus. 1980. Mutations affecting segment number and polarity in Drosophila. Nature 287: 795-801.

O'Hara, E.O., B. Cohen, S. Cohen, and W. McGinnis. 1993. Distal-less is a downstream gene of Deformed required for ventral maxillary identity. Development 117: 847-856.

Ohkuma, Y., M. Horikoshi, R.G. Roeder, and C. Desplan. 1990. Binding site-dependent direct activation and repression of in vitro transcription by Drosophila homeodomain proteins. Cell 61: 475-484.

Pick, L., A. Schier, M. Affolter, T. Schmidt-Glenewinkel, and W.J. Gehring. 1990. Analysis of the $f t z$ upstream element: Germ layer-specific enhancers are independently autoregulated. Genes \& Dev. 4: 1224-1239.

Pirrotta, V., E. Manet, E. Hardon, S.E. Bickel, and M. Benson. 1987. Structure and sequence of the Drosophila zeste gene. EMBO I. 6: 791-799.

Regulski, M., S. Dessain, N. McGinnis, and W. McGinnis. 1991. High-affinity binding sites for the Deformed protein are required for the function of an autoregulatory enhancer of the
Deformed gene. Genes \& Dev. 5: 278-286.

Rougvie, A. 1989. "Identification of a post-initiation rate-limiting step in the transcription of several Drosophila genes." Ph.D. thesis, Cornell University, Ithaca, New York.

Rougvie, A.E. and J.T. Lis. 1988. The RNA polymerase molecule at the $5^{\prime}$ end of the uninduced $h s p 70$ gene of D. melanogaster is transcriptionally engaged. Cell 54: $795-804$.

Rudnicki, M.A., P.N.J. Schnegelsberg, R.H. Stead, T. Braun, H. Arnold, and R. Jaenisch. 1993. MyoD or Myf-5 is required for the formation of skeletal muscle. Cell 75: 1351-1359.

Schier, A.F. and W.J. Gehring. 1992. Direct homeodomain-DNA interaction in the autoregulation of the fushi-tarazu gene. Nature 356: 804-807.

1993. Analysis of a fushi-tarazu autoregulatory element: Multiple sequence elements contribute to enhancer activity. EMBO J. 12: 1111-1119.

Schneider, I. 1972. Cell lines derived from late embryonic stages of Drosophila melanogaster. I. Embryol. Exp. Morphol. 27: 353-365.

Scott, M.P. and A.J. Weiner. 1984. Structural relationships among genes that control development: Sequence homology between the Antennapedia, Ultrabithorax and fushi tarazu loci of Drosophila. Proc. Nat1. Acad. Sci. 81: 4115-4119.

Stanojevic, D., T. Hoey, and M. Levine. 1989. Sequence-specific DNA-binding activities of the gap proteins encoded by hunchback and Kruppel in Drosophila. Nature 341: 331335.

Tanaka, M., U. Grossniklaus, W. Herr, and N. Hernandez. 1988. Activation of the U2 snRNA promoter by the octamer motif defines a new class of RNA polymerase II enhancer elements. Genes \& Dev. 2: 1764-1778.

Tautz, D. 1992. Redundancies, development and the flow of information. BioEssays 14: 263-266.

TenHarmsel, A., R.J. Austin, N. Savenelli, and M. Biggin. 1993. Cooperative binding at a distance by even-skipped protein correlates with repression and suggests a mechanism of silencing. Mol. Cell. Biol. 13: 2742-2752.

Treisman, J., P. Gönczy, M. Vashishtha, E. Harris, and C. Desplan. 1989. A single amino acid can determine the DNA binding specificity of homeodomain proteins. Cell 59: 553562.

Udvardy, A., E. Maine, and P. Schedl. 1985. The 87 A7 chromomere: Identification of novel chromatin structures flanking the heat shock locus that may define the boundaries of higher order domains. J. Mol. Biol. 185: 341-358.

Vachon, G., B. Cohen, C. Pfeifle, M.E. McGuffin, J. Botas, and S.M. Cohen. 1992. Homeotic genes of the bithorax complex repress limb development in the abdomen of the Drosophila embryo through the target gene Distal-less-less. Cell 71: 437-450.

Von Hippel, P.H., A. Revzin, C.A. Gross, and A.C. Wang. 1974. nonspecific DNA binding of genome regulating proteins as a biological control mechanism: 1. The lac operon: Equilibrium aspects. Proc. Natl. Acad. Sci. 71: 4808-4812.

Weiner, A.J., M.P. Scott, and T.C. Kaufman. 1984. A molecular analysis of fushi tarazu, a gene in Drosophila melanogaster that encodes a product affecting embryonic segment number and cell fate. Cell 37: 843-851.

Williams, K.R. and W.H. Konigsberg. 1991. Identification of Amino acid residues at interface of protein-nucleic acid complexes by photochemical cross-linking. Methods Enzymol. 208: 516-539.

Winslow, G.M., S. Hayashi, M. Krasnow, D.S. Hogness, and M.P. Scott. 1989. Transcriptional activation by the Antennapedia and fushi tarazu proteins in cultured Drosophila cells. Cell 57: 1017-1030. 


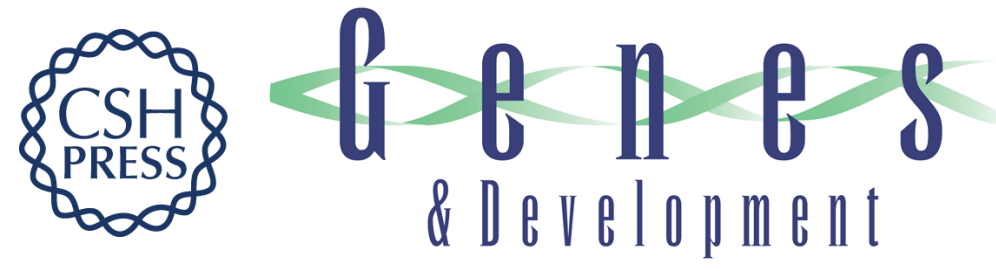

\section{Two homeo domain proteins bind with similar specificity to a wide range of DNA sites in Drosophila embryos.}

$J$ Walter, C A Dever and M D Biggin

Genes Dev. 1994, 8:

Access the most recent version at doi:10.1101/gad.8.14.1678

References This article cites 85 articles, 32 of which can be accessed free at:

http://genesdev.cshlp.org/content/8/14/1678.full.html\#ref-list-1

License

Email Alerting

Service

Receive free email alerts when new articles cite this article - sign up in the box at the top right corner of the article or click here.

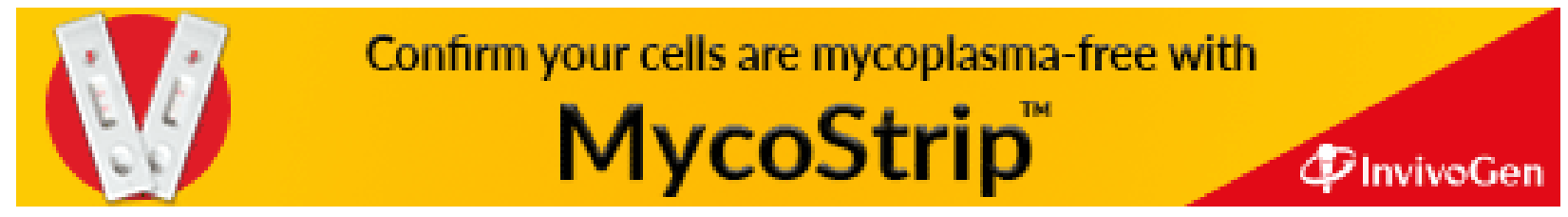

